\title{
Jakub Niedźwiedź
}

Uniwersytet Jagielloński, Kraków

jakub.niedzwiedz@uj.edu.pl

\section{Źródła, konteksty i okoliczności powstania Ody o zdobyciu Połocka Jana Kochanowskiego ${ }^{1}$}

\begin{abstract}
Sources, contexts and circumstances of the writing of An Ode on the Capture of Polatsk by Jan Kochanowski
\end{abstract}

The author set himself two aims. First, to demonstrate how the most important poet of the Polish Renaissance, Jan Kochanowski (1530-1584), participated in the propaganda campaign led by the chancery of the Polish King, Stephen Báthory, during the Livonian War in the year fought in the years 1577-1582. Second, to attempt to discover the sources and textual inspirations for the Ode on the Capture of Polatsk or Ode 12 (Warsaw 1580), a Latin propaganda work commissioned from the poet by the Chancellor of Poland, Jan Zamoyski. To this end, the author placed the ode in a broad context of sources from the epoch, such as poems, pamphlets, maps, letters, etc.

1 Artykuł powstał $\mathrm{w}$ ramach projektu badawczego MNiSW $\mathrm{nr}$ 2315/ H03/2006/31 pt. Twórczość Jana Kochanowskiego w kontekście nowołacińskiej literatury europejskiej i polskiej i w 2008 roku został opublikowany na stronie internetowej neolatina.bj.uj.edu.pl w dziale Studia pt. Oda XII De expugnatione Polottei wśród szesnastowiecznych (kon)teksów. Podrozdział Mapy i chorografie w obecnej wersji został uzupełniony o wyniki badań przeprowadzonych w ramach projektu NCN Opus (nr 2014/15/B/HS2/01104) Zwiazki literatury polskiej i kartografii w XVI - I poł. XVII w. 
In the first part of the paper, the circumstances that accompanied the writing of the ode are discussed. The author explains the relations between Kochanowski and Zamoyski and reminds the pressure exerted by the Chancellor on the poet, so that he quickly finishes texts that are supposed to praise the victory over Muscovites.

Kochanowski's writing technique is also discussed. The author notes that the poet's work resembled that of a philologist: preparing for writing a poem or a cycle of poems, Kochanowski made himself familiar with many various authorities. Thus he worked on the paraphrase of Psalterz (Psaltar 1579) and Treny (Laments 1580). According to the author, this was also Kochanowski's modus operandi when he was writing Ode 12 and other texts on the war with Muscovy. In this part of the paper, all his works related to this subject are briefly discussed.

In further parts, the author presents the sources that Kochanowski consulted when writing Ode 12. These include, first of all, previous poetic works, such as Horace's odes and Latin poems written after the victory in the Battle of Orsha (1514). The author demonstrates that Kochanowski drew inspiration e.g. from Carmen de victoria Sigismundi by Joannes Dantiscus. Another significant sources used by the poet were chronicles and chorographies of Muscovy (Herberstein, Gwagnin), as well as drawings and maps depicting the capture of Polatsk. He was probably provided with iconographic accounts by Zamoyski's messengers in January 1580. The author mentions that maps constituted a significant element of the chancery's propaganda strategy. In this part, he observes that the same sources were used by Kochanowski for his Jezda do Moskwy (The Ride to Muscovy 1583) and by Gerard Mercator for his map Russiae pars amplificata (1595).

The most important authorities consulted by Kochanowski included the accounts of the capture of Polatsk that he obtained directly from the royal chancery. In the last part of the study, the author compares several narrative sources with the ode. He arrives at the conclusion that the narration in Ode 12 basically reflects the description of the siege present in other sources and that it is very detailed for a lyrical work. He also shows the rhetoric means used by Kochanowski to intensify the propaganda effect.

At the end, the author places Ode 12 in the context of other renaissance utterances on the relation between history and poetry. He refers to the contemporary reflections of Antonio Minturno and Julius Caesar Scaliger.

Key words: Polish Renaissance poetry, Livonian War, propaganda literature, ode, Jan Kochanowski, Jan Zamoyski, Ivan IV Terrible, Stephen Báthory, Muscovy, the capture of Polatsk 1579, Renaissance cartography 
Wyobraźmy sobie jeźdźca na ośnieżonej równinie. Wraca z Czarnolasu do Warszawy. Pokonanie siedemnastu mil polskich zajmuje w tych warunkach co najmniej dwa dni, więc poseł $\mathrm{z}$ listem od pana Kochanowskiego jest wyraźnie zmęczony. Z Warszawy wyprawiono go 6 stycznia 1580 roku, a po czterech dniach był już z powrotem, skoro 10 stycznia kanclerz wielki koronny Zamoyski wysłał do Czarnolasu kolejnego posłańca. Odpowiedź na drugi list Kochanowski opatrzył datą 14 stycznia. Sprawa, której dotyczyła legacja, musiała być niezwykłej wagi. I taką była istotnie, gdyż dotyczyła poezji.

Zamieszczone tu rozważania poświęcę jednemu $\mathrm{z}$ czterech wierszy wydanych na początku 1580 roku, nie stracę jednak z pola widzenia kanclerskiego posłańca ${ }^{2}$, gdyż będzie on symbolizował wielowymiarową i niejednoznaczną relację między panem na Zamościu a panem na Czarnolesie. Soczewką skupiającą w sobie tę relację jest wiersz, a tym, co rzuca na niego światło, są inne dokumenty z XVI w. Chciałbym odpowiedzieć na pytanie, w jakich (kon)tekstach można go umiejscowić. W ten sposób zamierzam pokazać, jak na tym utworze Kochanowskiego odciskała się pieczęć (nie tylko kanclerska) władzy, polityki i propagandy. Innymi słowy, konteksty te ujawnią, jak bardzo złożonym i uwikłanym ideologicznie tekstem jest oda XII.

Łacińska Ode de expugnatione Polottei, czyli Oda o zdobyciu Połocka, opowiada o epizodzie z wojny Rzeczypospolitej z Moskwą w 1579 roku. Utwór ukazał się po raz pierwszy w Warszawie w drukarni Walentego Łapczyńskiego pół roku po opisywanych wypadkach, przed 21 lutego 1580 roku. Wznowiono go pod koniec tego roku jako ostatni, dwunasty wiersz z cyklu Lyricorum libellus ${ }^{3}$, jest

2 Na temat posłańców Zamoyskiego i funkcjonowania korespondencji w 2. poł. XVI w. zob. W. Tygielski, Listy, ludzie, władza. Patronat Jana Zamoyskiego w świetle korespondencji, Warszawa 2007, s. 25-33. O relacjach obu humanistów zob. J. Kowalczyk, Jan Kochanowski i Jan Zamoyski, w: Jan Kochanowski i epoka Renesansu. W 450 rocznice urodzin poety 1530-1980, red. T. Michałowska, Warszawa 1984, s. $262-281$.

3 Zob. P. Buchwald-Pelcowa, Dawne wydania dzieł Jana Kochanowskiego, Warszawa 1993, s. 90, 104, 108-111. 
więc określany również jako oda XII. Pozostałe trzy wiersze z 1580 roku wydane w tej samej drukarni Łapczyńskiego i przy tej samej okazji są polskimi pieśniami, które wyszły pod tytułem Pieśni trzy. Pieśń druga $\mathrm{z}$ tego krótkiego cyklu, zatytułowana $O$ wzięciu Połoc$k a$ i będąca polskojęzyczną wariacją na podstawie ody XII, została wznowiona już po śmierci Kochanowskiego jako pieśń 13 Pieśni ksiag wtórych ${ }^{4}$.

Interpretacja przeszłości, którą proponuję, będzie dość tradycyjna, gdyż oprze się na umieszczeniu utworu Kochanowskiego wśród innych tekstów kultury z jego czasów. Z rozległego ich repertuaru wybieram takie, które $\mathrm{z}$ punktu widzenia prowadzanej przeze mnie narracji, najlepiej do niej pasują: wiążą się bezpośrednio lub pośrednio z Odą o zdobyciu Połocka. Taka próba zarysowania rozleglejszego korpusu tekstów okalających utwór Kochanowskiego może być uzasadniana jego techniką pisania. Autor Lyricorum libellus zanim przystąpił do pracy nad jakimś większym utworem, zwykle otaczał się księgami i gromadził materiały, dziś powiedzielibyśmy: literaturę podmiotową i przedmiotową. Taki sposób pracy ujawniają co najmniej trzy teksty: Psałterz Dawidów, Treny oraz Jezda do Moskwy. Nie inaczej było w przypadku ody XII, co ukaże przedstawiana tu analiza. Część swoich źródeł Kochanowski ujawnia, obecności innych się domyślamy, jeszcze inne są przez niego staranie ukrywane, aby nie zdradzać wszystkich celów retorycznej perswazji.

4 W artykule będę się posługiwał następującymi skrótami na oznaczenie zbiorów poezji Jana Kochanowskiego: P - Pieśni ksiąg dwoje (I - Księgi pierwsze, II Księgi wtóre); J - Jezda do Moskwy; O - Lyricorum libellus. Korzystałem z następujących wydań: J. Kochanowski, Pieśni, oprac. L. Szczerbicka-Ślęk, Wrocław 2008; J. Kochanowski, Jezda do Moskwy, w: idem, Dzieła polskie, oprac. J. Krzyżanowski, Warszawa 1980, s. 639-652; J. Kochanowski, Lyricorum libellus, edycja internetowa na portalu neolatina.bj.uj.edu.pl, transkrypcja i przekład E. Buszewicz, objaśnienia E. Buszewicz, J. Niedźwiedź (2009). W roku 2010 ukazała się edycja ody XII: Z. Głombiowska, Łacińska oda Jana Kochanowskiego o zdobyciu Połocka. Tekst i komentarz, „Studia Classica et Neolatina” 9 (2010). 
Podejmuję zatem próbę odczytania kontekstualnego i historycystycznego. Przy tego typie interpretacji teksty z epoki są w zasadzie wszystkim, czym dysponujemy i jedynym punktem oparcia, ale też zarazem ograniczeniem, które - mam nadzieję - ujawni się w toku analizy.

\section{Moskiewskie poezje Kochanowskiego}

O wojnach moskiewskich Kochanowski pisał kilkakrotnie; najwcześniejsze wiersze należące do tej grupy pochodzą prawdopodobnie z 1567 roku: elegia otwierająca księgę trzecią z Elegiarum libri IV i pieśń 13 z Pieśni ksiag pierwszych. Oba powstały w związku $\mathrm{z}$ koncentracją armii litewsko-polskiej pod Radoszkowiczami niedaleko Mińska latem i jesienią 1567 roku $^{5}$. Jak się przypuszcza, Kochanowski jako sekretarz w kancelarii Zygmunta Augusta brał udział w tej wyprawie („straż dzierżem niecąc ognie aż do rana”, P I 13, 46). Jednak wojny prowadzone przez Stefana Batorego okazały się bardziej inspirujące niż zmagania z czasów pierwszej wojny północnej. Wszystkie trzy kampanie batoriańskie z lat 1579, 1580 i 1581-1582 znalazły odbicie w utworach polskich i łacińskich Kochanowskiego. W 1579 roku wyszła wspomniana już polska Pieśn o zdobyciu Połocka oraz Ode de expugnatione Polottei, w 1583 roku Jezda do Moskwy, w której poeta przedstawiał kawaleryjski zagon oddziałów Krzysztofa Radziwiłła „Pioruna” w głębi państwa moskiewskiego, i wreszcie było też łacińskie Epinicion opiewające Stefana Batorego, które zostało odśpiewane przez Krzysztofa Klabona na weselu Jana Zamoyskie-

5 Por. K. Piwarski, Niedoszła wyprawa radoszkowicka Zygmunta Augusta na Moskwę (rok 1567-1568), „Ateneum Wileńskie” 4 (1927), s. 256-286; M. Ferenc, Mikołaj Radziwiłt „Rudy” (ok. 1515-1584). Działalność polityczna i wojskowa, Kraków 2008, s. 310-311, 314.

6 Por. J. Pelc, Jan Kochanowski. Szczyt renesansu w literaturze polskiej, Warszawa 1980, s. 69. 
go i Gryzeldy Batorówny w 1583 roku. Odwołania do zmagań z Moskwą pojawiają się w tle kilku innych utworów, m.in. epitalamiach dla Krzysztofa Radziwiłła „Pioruna” (1578) i Jana Zamoyskiego (1583) oraz - jak się przypuszcza - w zakończeniu Odprawy posłów greckich (1578).

Dla dzisiejszego historyka literatury Kochanowski należy do wielu, którzy w poetycki sposób opowiedzieli wojny batoriańskie $\mathrm{f}^{7}$. Do najbardziej znanych należą poematy o wyprawie Krzysztofa Radziwiłła w 1581 roku i oblężeniu Pskowa. Prócz Kochanowskiego opisali je m.in. Andrzej Rymsza w Deketeros akroama, Franciszek Gradowski w Hodoeporicon Moschicum, Daniel Hermann w Stephaneis i kilku autorów włoskich w łacińsko-włoskiej antologii Viridarium poetarum - Giardino de' poeti (Wenecja 1583) ${ }^{8}$. Jednak zimą 1580 roku, kiedy poseł pana kanclerza Zamoyskiego cwałował do Czarnolasu, praktycznie nie było jeszcze żadnych utworów opiewających sukcesy pierwszej kampanii. Owszem, rozpowszechniano szereg relacji prozatorskich, głównie po polsku, po łacinie i po niemiecku, produkowanych $\mathrm{w}$ postaci gazet ulotnych redagowanych w kancelarii królewskiej ${ }^{9}$, ale utwór poetycki był tylko jeden, pióra Daniela Hermanna (ok. 1543-1601) ${ }^{10}$.

7 Por. J. Nowak-Dłużewski, Okolicznościowa poezja polityczna w Polsce. Pierwsi królowie elekcyjni, Warszawa 1969, s. 110-177; R. Krzywy, Sztuka wyborów i dar inwencji. Studium o strukturze gatunkowej poematów Jana Kochanowskiego, Warszawa 2008, s. 165.

8 Zob. A. Kappeler, Ivan Groznyj im Spiegel der ausländischen Druckschriften seiner Zeit: ein Beitrag zur Geschichte des westlichen Russlandbildes, Bern - Frankfurt a/M. 1972, s. 66-69. B. Awianowisz, Wstęp, w: E. Pielgrzymowski, Apostrofa panegiryczna, oprac. i przeł. B. Awianowicz, Warszawa 2012, s. 6.

9 Zob. J. Nowak-Dłużewski, Okolicznościowa poezja polityczna w Polsce. Pierwsi królowie elekcyjni..., s. 231.

10 D. Hermann, Musae Marti coniunctae. Ex regiis ad captam Polociam castris missae clarissimo viro doctori Jacobo Monaw, Vratislaviensi et ornatissimae viduae Susannae natae in honestissima familia Voglovium novis sponsis, Wilno 1579 (druk ten wyszedł w tym samym roku również we Wrocławiu). Zob. J. Nowak-Dłużewski, Okolicznościowa poezja polityczna w Polsce. Pierwsi królowie elekcyjni..., s. 113. 
Mimo że Hermann liczył się już jako poeta i postać publiczna, nie mógł dorównać sławie Kochanowskiego, „którego wirsze pod ten czas bardzo się już wsławiły", jak ujął to Łukasz Górnicki. Zapewne niedługo po zakończeniu kampanii, w ostatnim kwartale roku, Zamoyski zwrócił się do Kochanowskiego z prośbą o napisanie wierszy polskich i łacińskich, które w odpowiedni sposób upamiętniałyby zwycięstwo. Poseł na ośnieżonej równinie woził więc ze sobą teksty, które miały zdyskontować zwycięstwo króla Stefana oraz pana kanclerza i jednocześnie stworzyć podstawy do kolejnych sukcesów.

Na przełomie roku 1579 i 1580 został zwołany do Warszawy sejm, który miał zadecydować o sfinansowaniu kolejnej kampanii wojennej. Dawni badacze przypuszczali, że Zamoyski zlecił swojemu poecie napisanie wierszy propagandowych w celu rozkolportowania ich $\mathrm{w}$ trakcie sejmu ${ }^{11}$, jednak posłańcy jeździli do Czarnolasu, a Łapczyński drukował pieśni już po zakończeniu obrad. Cel pana kanclerza i pomysł na propagowanie zwycięstwa musiały być bardziej dalekosiężne niż doraźne przekonywanie posłów, by zechcieli „przekuwać talerze na talery". Trudno stwierdzić, czy pośpiech Zamoyskiego był spowodowany chęcią uświetnienia tymi utworami wesela jego przyrodniej siostry ${ }^{12}$, gdyż kanclerzowi ówcześnie zależało bardziej na walorach propagandowych niż epideiktycznych poezji wojennej służącej rozrywce gości weselnych.

Jeśli wierzyć listowi z 14 stycznia, który został wydrukowany w zbiorze Pieśni trzy, Zamoyski przymusił Kochanowskiego do napisania wierszy: „I stękać mi, Wasza Miłość, nie dasz, więc nie wiem,

Teksty propagandowe skierowano przede wszystkim do audytorium niemieckiego (por. „Polnische Zeitung” 1580, gdzie znalazła się szczegółowa relacja z przebiegu kampanii połockiej) i włoskiego (por. Basilius Hyacinthius Vilnensis, Panegyricus in excidium Polocense..., Padova 1580; J. Nowak-Dłużewski Okolicznościowa poezja polityczna w Polsce. Pierwsi królowie elekcyjni..., s. 224, przyp. 19).

${ }_{11}$ Zob. J. Nowak-Dłużewski, Okolicznościowa poezja polityczna w Polsce. Pierwsi królowie elekcyjni..., s. 120.

12 Zob. J. Kowalczyk, Jan Kochanowski i Jan Zamoyski.., s. 273; P. Buchwald-Pelcowa, Dawne wydania..., s. 100. 
mam-li to od Waszej Miłości sobie za krzywdę brać”. Mimo że poecie nie bardzo było na rękę pisanie wierszy, godzi się on spełnić życzenie patrona: „Jeśli co nie k rzeczy (a bodaj nie wszytko), któż winien? Ja naprzód, a Wasza Miłość też po części, qui scribere cogis [który zmuszasz do pisania], chocia zły aspekt”"13. Większość badaczy wiąże ów „zły aspekt” ze śmiercią córek poety. Zastanawia jednak, dlaczego Zamoyski przystał na wydrukowanie prywatnego listu jako listu dedykacyjnego? Być może utyskiwania poety na niską jakość przygotowanych naprędce wierszy należałoby traktować jako topos skromności, tym bardziej że w późniejszych edycjach pieśni i ód Kochanowski wprowadził niewiele zmian, więc nie mogły być one uznawane przez poetę za złe. Nie dowiemy się ponadto, czy poeta wiedział, że jego list do Zamoyskiego zostanie wydrukowany. Ponieważ w piśmie bardzo mocno podkreślone jest osobiste zaangażowanie, wręcz natręctwo Zamoyskiego, musiało to być w jakiś sposób dla niego korzystne, skądinąd wiemy bowiem, jak dużą wagę przywiązywał kanclerz do propagandowego znaczenia epistolografii ${ }^{14}$. W tym wypadku mogło chodzić o wyraz poparcia dla polityki pana kanclerza, na pewno zaś o ujawnienie zażyłości między obu humanistami.

Publiczne przyznanie się do zabiegów o pozyskanie wierszy Kochanowskiego przez tak znaczącego polityka, jakim był Zamoyski, potwierdza rangę autora Trenów: jest on już na tyle rozpoznawalną „marką", że posłużenie się nią wzmacnia autorytet przekazu. Jednocześnie na zasadzie sprzężenia zwrotnego Kochanowski (poprzez osobę Zamoyskiego) zyskuje potwierdzenie swojej skuteczności perswazyjnej, co podnosi jego pozycję jako poety-oratora, poety publicznego i stwarza nadzieję pozyskania związanych z tym korzyści. Tę relację daje się opisać przy pomocy kategorii właściwych charakte-

13 J. Kochanowski, Pieśni trzy. O wzięciu Połocka. O statecznym słudze R. P. O uczciwej małżonce, Warszawa 1583, k. A v. (http://www.polona.pl/dlibra/docc ontent 2 ? id=85\&from=editionindex \&from=-3search\&dirids=20\&lang=pl, dostęp: 19.06.2010).

14 Zob. W. Tygielski, Listy, ludzie, władza..., s. 305-309. 
rystyce stosunków klientarnych. Wymagają one m.in. wzajemności, a zatem obopólnych zysków, są też dyktowane układem zewnętrznym, w którym patron musi zlecać poecie tworzenie wierszy, poeta zaś musi wiersze pisać ${ }^{15}$. Do pewnego stopnia humanistom takim jak Zamoyski i Kochanowski całkiem łatwo było się odnaleźć w sytuacji podobnej „nierównej przyjaźni”, a to poprzez lekturę rzymskich poetów doby augustowskiej. Dzięki temu porozumieniu dochodziło nie tylko do politycyzacji poezji, ale również do poetycyzacji dyskursu politycznego $^{16}$.

\section{Horacy}

Niebezpiecznie jest dziś mówić o intencjach autorskich, ale wskazówki zawarte w wierszu pozwalają co nieco powiedzieć o retorycznych właściwościach utworu. Do uruchomienia retorycznej perswazji służy Kochanowskiemu przede wszystkim horacjanizm - czytelnicy, którzy należą do tej samej wspólnoty interpretacyjnej co on, rozpoznają idee rzymskiego poety w podobny sposób jak poeta polski (lub w ogóle szesnastowieczny) i dostają wskazówkę, swoistą instrukcję obsługi wiersza. Mają go czytać zgodnie z kluczem właściwym dla interpretacji wierszy horacjańskich, który został im wpojony w trakcie edukacji w szkole lub w trakcie prywatnej lektury. Rozpoznaja więc sposób interpretacji zanim jeszcze do niej na dobre przystąpią.

15 Por. M. Brennan, Literary Patronage in the English Renaissance: The Pembroke Family, London - New York 1988, s. 1-18; K. M. Dmitruk, Wokót teorii i historii mecenatu, w: $Z$ dziejów mecenatu kulturalnego w Polsce, red. J. Kostecki, Warszawa 1999, s. 29-30; J. Mączak, Nierówna przyjaźn. Układy klientalne w perspektywie historycznej, Wrocław 2003, s. 44-46.

${ }_{16}$ Zob. D. Norbrook, Poetry and Politics in the English Renaissance, London 1984, s. 4-5. 
Szesnastowieczni czytelnicy ody XII bez trudu zatem odnajdywali w niej rzymską matrycę, którą były trzy ody Horacego ${ }^{17}$. Głównym wzorem była oda $14 \mathrm{z}$ księgi IV (Quae cura patrum quaeve Quiritum), opiewająca zwycięstwa Augusta, a właściwie jego pasierbów, Druzusa i Tyberiusza Neronów ${ }^{18}$, którzy w roku 15 p.n.e. podbili germańskich Windelików. Kolejnym punktem odniesienia była oda 37 z księgi pierwszej, zaczynająca się od słów Nunc est bibendum i sławiąca zwycięstwo Oktawiana pod Akcjum w 31 roku p.n.e. Dodatkowy kontekst może stanowić oda IV 4, również poświęcona zwycięskim Druzusowi i Tyberiuszowi ${ }^{19}$.

Kochanowski przejął od swojego mistrza nie tylko występujące we wszystkich trzech utworach metrum alcejskie, ale również topikę i w zasadniczym zarysie schemat kompozycyjny. Takich zabiegów intertekstualnych spodziewaliby się po Kochanowskim zarówno publiczność literacka z czasów Batorego, jak i dzisiejsi badacze. Ukształtowanie tekstu rzymskiego poety, język i dykcja poetycka były ówcześnie na tyle czytelne i oczywiste, że niemal przeźroczyste, zatem wybór horacjańskiego języka poetyckiego wydawał się jak najbardziej naturalny. Z tego też powodu w różnych częściach Europy XVI-XIX wieku epinikiony wzorowane na Horacym dostarczały

17 Zob. W. Ryczek, Stodkobrzmiace pieśni. Epinicion Jana Kochanowskiego - (re) konstruowanie poetyki, w: Wiązanie sobótkowe. Studia o Janie Kochanowskim, red. E. Lasocińska, W. Pawlak, Warszawa 2015, s. 153-154.

18 Zob. J. Glomsky, Historiography as Art: Jan Kochanowski's „Lyricorum libellus" (1580), w: Renaissance Culture in Context. Theory and Practice, ed. by J.R. Brink, W.F. Genturp, Aldershot - Brookfield 1993, s. 152.

19 Kochanowski wyraźnie odwołuje się w tych odach do tradycji pindaryckich, ale poprzez źródła włoskie. Wiadomo, że Kochanowski też znał pieśni Pindara i inspirował się nimi w późniejszym Epinicionie i Epitalamium dla Zamoyskiego (1583), jednak nie należałoby dostrzegać wpływu poety greckiego na odę XII w takim stopniu, w jakim to miało miejsce w Epinicionie, por. Z. Głombiowska, O pindaryzmie Epinicionu Jana Kochanowskiego, w: Jan Kochanowski. Interpretacje, red. J. Błoński, Kraków 1989, s. 18-35; J. Glomsky, Historiography as Art..., s. 147-148; E. Buszewicz, Forma gatunkowa ody w łacińskiej poezji Jana Kochanowskiego, „Terminus”, 16 (2014), z. 1 (30), s. 24-25. 
możliwości chwalenia aktualnych zwycięstw, np. w tomie Schediasmata poetica (Paryż 1586) ${ }^{20}$, Andrew Marwella, który pisał o Cromwellu wracającym z podboju Irlandii ${ }^{21}$, lub Kajetana Koźmiana, opiewającego triumfy Napoleona ${ }^{22}$.

Pewne elementy tekstu, które z punktu widzenia współczesnego czytelnika mogą się wydawać niewiele znaczącym ozdobnikiem lub wręcz świadczyć o nieporadności poety i nieumiejętności panowania nad dyskursem $\mathrm{w}$ wierszu, są $\mathrm{w}$ istocie niezbywalnymi elementami „gramatyki” horacjańskiego wiersza, zaś rezygnacja z nich przypominałaby usunięcie orzeczenia lub części dopełnień ze zdania.

Dzięki lekturze wierszy Horacego Kochanowski uczy się języka, w którym może mówić o władcy, historii i przeznaczeniu, a właściwie o przeznaczeniu, które sprawia, że we władcy ucieleśnia się historia. Rozumowanie to jest nałożone na kompozycję przypominającą zarazem odę IV 14 i schemat klasycznej mowy zbudowanej według zasad sztuki retorycznej. Oda zaczyna się od apostrofy do Melpomeny, rozumianej tu jako muza poezji epickiej, która ma opiewać czyny i cnotę króla (w. 1-4). Po takim egzordium Kochanowski wprowadza propositio - przedstawienie tematu, którym jest odzyskanie Połocka (w. 5-8) i cnota królewska (w. 9-24). Najdłuższa część stanowi uzasadnienie (argumentatio) w postaci długiej narracji opowiadającej o zdobyciu Połocka (w. 25-92). Ostatnie dwie strofy (w. 93-100) przynoszą rekapitulację, gdzie mowa jest o sprzyjających bogach, męstwie Batorego i gdzie kolejny raz pojawia się wezwanie do śpiewu ku czci monarchy, choć tym razem do Melpomeny mają się dołączyć wszyscy jego poddani.

20 Zob. W. Ryczek, Słodkobrzmiace pieśni..., s. 152-153.

21 Zob. F. Kermode, Poetry and History, w: idem, Poetry, Narrative, History, Cambridge, MA, 1990, s. 55-60.

22 Por. np. Oda na wojnę w roku 1800, ukończona batalia pod Marengo lub Oda na pożar Moskwy, w: K. Koźmian, Wybór poezji. Ody napoleońskie. Wiersze różne. Ziemiaństwo polskie (fragmenty). Stefan Czarniecki (fragmenty), wyd. R. Dąbrowski, Kraków 2002, s. 7-8 i 17-20. 
W tej retorycznej strukturze zadaniem czytelnika jest odnalezienie idei o opatrznościowym wymiarze zwycięstwa i rozpoznanie w Batorym kolejnego „Oktawiana Augusta”23, narzędzia „bogów” i „fatum”, czyli - przekładając na rzeczywistość szesnastego wieku - Opatrzność Boską. Aby ułatwić czytelnikowi dostrzeżenie tych intertekstualnych zabiegów w odniesieniu do postaci Batorego, poeta uruchamia zabiegi, które dzisiejszemu, nieobeznanemu z Horacym, mogą się wydawać zupełnie zbędne.

W części, którą określiłem jako propositio, Kochanowski dwukrotnie użył porównania homeryckiego. W pierwszym porównał Batorego do lwa, przed którym ucieka Iwan Groźny, czyli wilk, w drugim mamy obraz wylewającej rzeki i powodzi, przed którą na wzgórzu chroni się pasterz ze swoją trzodą. Oczywiście powodzią są armie królewskie, a wzgórzem jest Połock. Od tego drugiego porównania zacznie się opis oblężenia miasta. Kochanowski posłużył się figurą distributio, w której jednemu elementowi - królowi - zostały podporządkowane dalsze elementy wywodu - dwa porównania homeryckie odnoszące się do działań Moskali. Jednak istotniejsze od zabiegu retorycznego jest źródło porównań.

Pierwsze porównanie było zainspirowane Horacjańską odą IV 4, w której kózka ucieka przed lwem (Druzusem; w. 13-16). W drugim poeta odwołuje się do porównania z ody IV 14, w której rzeka Aufidus, symbolizująca armię rzymską, zalewa wszystko, co stanie na jej drodze. Porównania te wraz z kilkoma innymi bezpośrednimi nawiązaniami horacjańskimi ${ }^{24}$ mają przywiązać czytelnika do jedynej pożądanej interpretacji: opowieści o słusznym zwycięstwie prawa, porządku, religii, etyki, pokoju, sprawiedliwości, kultury nad barbarzyństwem, dzikością, okrucieństwem i tym wszystkim, co po łaci-

23 Zob. J. Glomsky, Historiography as Art..., s. 152.

24 Por. „rigido meti inulta ferro" (O XII 44) - „primosque et exteremos metendo" (Hor. Carm. IV 14,31); „Dic bis novenas per hiemes truci/ Tandem receptum ex hoste Polotteum” (O XII 44) - „Fortuna lustro prospera tertio/ belli secundos red-didit exitus" (Hor. Carm. IV 14,37); narracja bitewna i radość ze zwycięstwa w Hor. Carm. I 37. 
nie zwykło się określać jako inhumanitas. W ten sposób Kochanowski staje po stronie imperialnej poetyki zwycięzców, którzy stwarzają porządek świata i wypływający z niego porządek poezji ${ }^{25}$. Poetyce tej patronuje Horacy, a przede wszystkim jego przyjaciel Wergiliusz.

\section{Cykl orszański}

Pierwszym „Oktawianem Augustem” w poezji polskiej był Zygmunt Stary, a uczynili go nim poeci tworzący na jego dworze lub z tym dworem związani. Początek jego panowania przyniósł znaczącą zmianę $\mathrm{w}$ uprawianiu propagandy państwowej i jej szersze niż dotychczas wykorzystanie $\mathrm{w}$ dyplomacji ${ }^{26}$. Ta zmiana odbywała się zresztą nie tylko w królestwie polskim, gdyż obejmowała ona w większym lub mniejszym stopniu wszystkie większe kraje europejskie. Kształtowanie wizerunku władcy, jego polityki, obrazu państwa itd. w bardziej efektywny sposób było możliwe, gdyż zapewniały je dwie nowe formy komunikacji: łacińska literatura humanistyczna i druk ${ }^{27}$.

Poeci króla Zygmunta I wprowadzili temat wojny z Moskwą do poezji łacińskiej. Okazji dostarczyło przede wszystkim zwycięstwo pod Orszą odniesione 8 września 1514 roku przez hetmana Konstantego Ostrogskiego. Była to jedna $\mathrm{z}$ pierwszych zmasowanych kampanii propagandowych prowadzonych przez kancelarię Zygmunta Starego. Ważnym jej uczestnikiem i zapewne współtwórcą

25 Zob. D. Quint, Epic and Empire. Politics and Generic Form from Virgil to Milton, Princeton 1992, s. 9-10.

26 Zob. H. Grala, Jeńcy spod Orszy: między jagiellońska „propaganda suckesu” a moskiewska racja stanu (1514-1552), w: Aetas media - aetas moderna. Studia ofiarowane profesorowi Henrykowi Samsonowiczowi w siedemdziesiąta rocznicę urodzin, Warszawa 2000, s. 439-442.

27 Por. A.F. Marotti, Patronage, Poetry, and Print, „The Yearbook of English Studies" 21 (1991): Politics, Patronage and Literature in England 1558-1658. Special Number, s. 1-26. 
był dyplomata królewski Jan Dantyszek (1485-1548). Już 23 września, piętnaście dni po bitwie, wydał u Hallera pisany heksametrem poemat Sylvula de victoria inclyti Sigismundi regis Poloniae contra Moschos, do którego dołączono wiersz Walentego Ecka o podobnej tematyce ${ }^{28}$. Niedługo później kolejni poeci łacińscy wydrukowali swoje utwory, które rozsyłano po całej Europie wraz z relacjami o zwycięstwie opracowanymi przez kancelarię królewską. Papieżowi i cesarzowi wysłano zresztą w prezencie kilku jeńców ${ }^{29}$. Rok po zwycięstwie wydano w Rzymie, $\mathrm{z}$ inspiracji prymasa i dyplomaty królewskiego Jana Łaskiego, który tam przebywał, antologię niemal wszystkich wydanych dotychczas utworów poświęconych bitwie orszańskiej: prócz wierszy Dantyszka i Ecka znalazły się tam teksty Andrzeja Krzyckiego, Krzysztofa Suchtena, Bernarda Wapowskiego, Jacoba Pisy i Tranquilla Androniciusa ${ }^{30}$.

Dowodem na inspirowanie się przez Kochanowskiego antymoskiewskim epinicjonem Jana Dantyszka z 1514 roku jest „recycling” pewnego toposu. Wers $85 \mathrm{z}$ Jezdy do Moskwy jest niemal dokładnym tłumaczeniem wersu 42 z Carmen de victoria Sigismundi Dantyszka:

Moskiewski, komu grożąc, sam się teraz boi

Qui fuerat nuper metuendus, nunc timet ipse

[Ten, który dawniej miał być straszny, teraz boi się sam] ${ }^{31}$

28 Zob. J. Nowak-Dłużewski, Okolicznościowa poezja polityczna w dawnej Polsce. Czasy zygmuntowskie, Warszawa 1966, s. 58.

29 Zob. H. Grala, Jeńcy spod Orszy..., s. 444-446.

${ }_{30}$ Zob. ibidem, s. 52; J. Glomsky, Patronage and Humanist Literature in the Age of the Jagiellons. Court and Career in the Writings of Rudolf Agricola Junior, Valentin Eck and Leonard Cox, Toronto - Buffalo - London 2007, s. 131; M. Čiurinskas, Pergalès prie Oršos (1514) propaganda Europoje: šaltiniu apžvalga, literatūriniai bei kultūriniai aspektai, „Senoji Lietuvos Literatūra” 21 (2006), s. 317-341.

${ }_{31}$ Cytaty z utworu Dantyszka pochodzą z edycji: J. Dantyszek, Carmina, wyd. S. Skimina, Kraków 1950. 
Istotniejsze, jak się wydaje, niż udowadnianie, czy i w jakim stopniu Kochanowski korzystał z poezji poetów tworzących cykl o bitwie pod Orszą, jest raczej zastanowienie się, w jaki sposób przekształcał istniejącą już topikę i do czego mu się ona przydawała. Dzięki temu można będzie coś więcej powiedzieć o technice poetyckiej wszystkich wspomnianych poetów, o zmieniającej się na przestrzeni XVI wieku propagandzie, o wykorzystaniu przez nią literatury, poszukującej coraz to nowych i skuteczniejszych form perswazyjnych.

Głównym tekstem z cyklu orszańskiego był, jak się wydaje, wspomniany krótki poemat Jana Dantyszka ${ }^{32}$. W istocie jest więcej rzeczy, które różnią wiersze Kochanowskiego i Dantyszka, niż czynią je do siebie podobnymi. Dyplomata Zygmunta I pisze heksametrem, jego narracja jest dość ogólnikowa, gdyż najwyraźniej nie dotarły jeszcze szczegółowe relacje z bitwy, a forma wiersza, z czym się zgadza większość badaczy, jest niedopracowana, co wynikało z pośpiechu oraz improwizacji, do czego przyznawał się sam autor ${ }^{33}$. Wprawdzie Kochanowski też się przyznawał do improwizowania, ale jego oda jest wycyzelowana i trudno by jej było postawić zarzuty niewłaściwego słownictwa i błędów w metryce łacińskiej, jak to bywa w przypadku Dantyszka. Kochanowski precyzyjnie opisuje bitwę, zna relacje, a na dodatek posługuje się wyrafinowaną formą horacjańską.

Pozostają jednak zbieżności w warstwie topicznej: uciekający władca Moskiewski ${ }^{34}$; ukaranie pychy księcia moskiewskiego; wycinanie wrogów twardym żelazem. Najważniejsza wydaje się jednak teza o zwycięstwie sprawiedliwości i o wsparciu słusznej sprawy przez Boga. U Dantyszka „Wszechmocny Ojciec (...) powalił

32 Por. J. Glomsky, Patronage and Humanist Literature..., s. 132.

33 Por. M. Brożek, Ambicje improwizatorskie poetów polsko-łacińskich XVI w., w: Łacińska poezja w dawnej Polsce, red. T. Michałowska, Warszawa 1995, s. 30.

34 Fragment ten o ucieczce hardego Iwana Groźnego analizował R. Krzywy, „Chcesz być groźnym, a uciekasz...”. Nad komentarzem do epinikionów moskiewskich Jana Kochanowskiego, „Pamiętnik Literacki” 104 (2013), 3, s. 185-193. 
nieprawych”35 (w. 3 i 6), i dalej: „Pod przewodnictwem [Zygmunta] zostały powalone tysiące Moskali” (w. 35), zatem Bóg i Zygmunt działają we wspólnej sprawie. Podobną koniunkcję sprawiedliwości boskiej i ziemskiej dostrzegamy u Kochanowskiego: „Połock został po osiemnastu latach o d e b r a n y okrutnemu wrogowi dzięki pomocy niebian" (s. 93-95). Władca moskiewski został zatem skarany za swoją pychę (jeszcze mocniej jest to wyrażone w pieśni $O$ wzięciu Połocka), a Rzeczpospolita odzyskała należne jej ziemie. Dantyszek i Kochanowski podnoszą zatem w swoich wierszach kwestię słuszności roszczeń polskiego władcy, co należy wiązać z przeznaczeniem obu pieśni na eksport.

Drugi z liczących się poetów i dworzan z początku XVI wieku, Andrzej Krzycki (1482-1537), wybrał inny niż Dantyszek sposób pisania o bitwie i na pierwszy rzut oka niemający nic wspólnego $\mathrm{z}$ odą Kochanowskiego. Otóż formą stroficzną w Cantilena de victoria e Moscis parta $(1515)^{36}$ jest trzywersowa i rymowana zwrotka wzorowana na Stabat Mater, dobrze ugruntowana w poezji średniowiecznej ${ }^{37}$, choć uprawiana w poezji łacińskiej co najmniej do XVII wieku. A zatem pod tym względem utwór Krzyckiego znajdowałby się na antypodach tekstu Kochanowskiego. Co więcej, podobieństwa $\mathrm{z}$ odą XII, takie jak radosne wykrzyknienia na początku, motyw pychy władcy moskiewskiego czy sprawiedliwego zwycięstwa króla polskiego są dość oczywiste i występują w innych utworach orszańskich. Są jednak trzy zbieżności z odą Kochanowskiego, które każą przypomnieć ten długi, liczący 368 wersów utwór.

Pierwszą jest jego meliczność - wiersz był przeznaczony do śpiewania, tak jak Epinicion Kochanowskiego, Pieśni trzy i oda XII. W znaczny sposób mogła ona poszerzyć - przynajmniej potencjal-

35 „Omnipotens Genitor [...] prosternit iniquos”; „Te duce prostrati Moscorum milia multa”.

36 A. Krzycki, Cantilena de victoria a Moscis parta die natali Sanctae Mariae 1514 rem summarie continens, w: A. Krzycki, Carmina, wyd., wstęp i oprac. K. Morawski, Kraków 1888, s. 42-53.

37 Por. L. Pszczołowska, Wiersz polski. Zarys historyczny, Wrocław 1997, s. 49-50. 
nie - liczbę odbiorców tych utworów. Ponadto jej meliczność miała niebagatelne znaczenie mnemotechniczne i tak niemałe dzięki wierszowanej formie przekazu.

Cecha druga: mimo że autor w czasie bitwy przebywał w Krakowie, dokładnie opisał jej przebieg, co oznacza, że opierał się na opowieściach uczestników lub - na co w większym stopniu zdaje się wskazywać jego wiedza - na spisanych relacjach z kancelarii królewskiej, do której jako sekretarz królowej miał dostęp. Krzycki pisze o składzie armii litewsko-polskiej, jej wodzach, zbliżaniu się wojsk do Dniepru, niespodzianej dla Moskali przeprawie przez rzekę, szarży konnicy, próbach oskrzydlenia wojsk litewskich, a nawet o wciągnięciu wroga w zasadzkę i ostrzelaniu go $\mathrm{z}$ armat ${ }^{38}$ na skraju wąwozu.

Po trzecie wreszcie, utwór Krzyckiego mógł być nie tylko inspirowany opisami bitwy, ale również jej przedstawieniami plastycznymi lub kartograficznymi. Mapy i rysunki wyobrażające etapy bitwy stanowiły nieodłączny składnik relacji z bitwy, którymi dysponowała kancelaria królewska. Bez wizualizacji, której można dokonać przy pomocy mapy, trudno sobie wyobrażać ruchy wojsk i ich rozmieszczenie opisane $\mathrm{w}$ kantylenie. $\mathrm{Na}$ podstawie takich właśnie przedstawień kartograficznych anonimowy artysta z kręgu Łukasza Cranacha starszego namalował propagandowy obraz Bitwa pod Orsza, znajdujący się obecnie w Muzeum Narodowym w Warszawie ${ }^{39}$.

Drzeworytnicze narracje z pola walki stały się popularne w pierwszych dziesięcioleciach XVI wieku w pobliskich krajach Rzeszy ${ }^{40}$. Czytelnikom przestały wystarczać opowieści i opisy, chcieli oglądać

38 Zarówno Krzycki, jak i Kochanowski piszą w swoich wierszach o użyciu artylerii, przy czym Krzycki posługuje się późnośredniowiecznym neologizmem bombarda, podczas gdy Kochanowski używa słowa tormentum, które było neologizmem leksykalnym, zaczerpniętym z literatury rzymskiej.

39 Zob. M. Janicki, Obraz Bitwa pod Orsza - geneza, datowanie, wzory graficzne a obraz bitwy „na Kropiwnej” i inne przedstawienia batalistyczne w wileńskim pałacu Radziwiłłów, w: Bitwa pod Orszą, red. M. Nagielski, Warszawa 2015, s. 173-223.

40 Szczególne pole do popisu dawały widoki bitew i oblężeń. Szerzej piszą o tym Ph. Benedict, Graphic History. The Wars, Massacres and Troubles of Tortorel and Par- 
sprawozdanie z bitwy własnymi oczami. Zatem na obrazie Bitwa pod Orszą i w kantylenie Krzyckiego pojawiają się sekwencyjnie te same wydarzenia. Oba dzieła nawzajem się komentują, podobnie jak słowo i obraz we współczesnym komiksie. Warto nadmienić, że pierwsze wydanie kantyleny Krzyckiego zaopatrzone zostało w drzeworyt przedstawiający bitwę pod Orszą ${ }^{41}$. Przedstawienie tej bitwy znalazło się również w drugim wydaniu Kroniki Bielskiego $(1564)^{42}$.

Kiedy sześćdziesiąt pięć lat później Kochanowski pisał odę XII i pieśń $O$ wzięciu Połocka narracje łączące słowo, obraz i kartografię były na porządku dziennym.

\section{Mapy i chorografie}

Kochanowskiego, podobnie jak chyba wszystkich współczesnych mu humanistów, ciekawiły mapy ziemi ${ }^{43}$ i nieba, opisy geograficzne, czyli chorografie, narracje podróżnicze. W mapę nieba zaopatrzona jest jego edycja Aratosa. W odach i pieśniach znajdujemy zaledwie cień tych zainteresowań (np. w P II $24^{44}$ ), na powierzchni tekstu nie widać ich od razu, lecz poeta prowadzi swoją opowieść o wojnie moskiewskiej, będąc pod wpływem obu sposobów opisywania ziemi:

rissin, Genève 2007, s. 75-121, oraz M. Pollak, Cities at War in Early Modern Europe, New York 2010, s. 109-153.

41 Ibidem, s. 189-190.

42 Zob. H. Grala, Jeńcy spod Orszy..., s. 442.

43 Por. R. Helgerson, The Land Speaks: Cartography, Chorography, and Subversion in Renaissance England, w: Representing the English Renessance, ed. by S. Greenblatt, Berkeley 1988, s. 327-361; D. Woodward, Cartography and the Renaissance: Continuity and Change, w: The History of Cartography, t. 3, Cartography in the European Renaissance, ed. by D. Woodward, Chicago 2007, s. 3-24.

${ }_{4}$ Zob. J. Niedźwiedź, Humanistyczna mapa Europy Jana Kochanowskiego (Pieśn 24 Ksiąg wtórych), w: Literatura renesansowa $w$ Polsce i Europie. Studia dedykowane Profesorowi Andrzejowi Borowskiemu, red. J. Niedźwiedź, Kraków 2016, s. $251-273$. 
chorografii i kartografii. Co zatem wynika dla naszego rozumienia tekstów z lektury szesnastowiecznych deskrypcji Moskwy?

Osią geograficzną był dla Kochanowskiego kierunek południepółnoc. Moskwa nie leżała na wschodzie, lecz na dalekiej północy, gdyż punktem odniesienia dla ówczesnych humanistów była Italia. Również Polskę i Litwę charakteryzowano przy pomocy kategorii septentrionalnych, jednak Moskwa należała do krajów jeszcze bardziej północnych, oddalonych od cywilizacji południa, Rzymu, Latinitas i humanitas. Na wieść o wojnie Iwan Groźny, „tyran północnej strony" (P II 13,6) uciekał więc w głąb swojego kraju, czyli, jak to ujął poeta, „ubezpieczył się i spiąwszy ostrogą skrzydlatego konia, podążył galopem aż tam, gdzie się rodzi mroźny Boreasz" (O XII 29-32), a „nie oparł się aż o lody / niepławnej północnej wody” (P II 13, 1-12).

Kochanowski, podobnie jak większość ówczesnych autorów piszących o Moskwie, charakteryzował państwo carów jako zimną, północną krainę. Nie wiemy, kto i co opowiadał Kochanowskiemu o Moskwie, a zapewne miał do czynienia $\mathrm{z}$ bezpośrednimi relacjami osób, które nieźle znały ten kraj, np. z Krzysztofem Radziwiłłem „Piorunem”, jednak wiemy, jakie książki o Moskwie i jakie mapy mógł z dużym prawdopodobieństwem znać, ponieważ były one nie tylko dostępne, ale też - jako dzieła donoszące o mało znanej części Europy - stanowily dla szesnastowiecznych humanistów zajmującą lekturę.

Na potrzeby kampanii 1579 roku Batory wespół z Zamoyskim zatrudnili kilku kartografów. Między nimi byli z pewnością dwaj sekretarze królewscy: Stanisław Pachołowiecki (2. poł. XVI w. $)^{45}$ i Ma-

45 Zob. K. Buczek, Kartografia polska w czasach Stefana Batorego, Warszawa 1933, s. 80-81; idem, Dorobek kartograficzny wojen Stefana Batorego „Wiadomości Służby Geograficznej” 1934, z. 3, s. 253-256; idem, Dzieje kartografii polskiej od XV do XVIII wieku. Zarys analityczno-syntetyczny, Warszawa 1963, s. 40-41; S. Alexandrowicz, Nowe źródło ikonograficzne do oblężenia Połocka w 1579 r., „Kwartalnik Historii Kultury Materialnej” 19 (1971), nr 1, s. 4-15; idem, Źródła kartograficzne do wyprawy połockiej Stefana Batorego roku 1579, w: Od armii komputowej do 
ciej Strubicz (ok. 1530-ok. 1605) ${ }^{46}$. Drugi z nich, pełniący funkcję sekretarza już w czasach Zygmunta Augusta ${ }^{47}$, musiał znać Jana Kochanowskiego, podobnie zresztą jak poeta pracował dla pana kanclerza. W liście do Zamoyskiego z 1 listopada 1579 roku Strubicz nadmienia o mapie, którą przygotował na potrzeby kampanii i której kopię ma sporządzić w ciągu sześciu tygodni ${ }^{48}$.

Z kolei Pachołowiecki, który brał udział w wyprawie połockiej, wyrysował mapę Księstwa Połockiego i plany oblężenia Połocka, tworząc pierwszy regionalny atlas polski ${ }^{49}$. Jeden $\mathrm{z}$ nich, przedstawiający stan oblężenia z 11 sierpnia, a także wspomniana mapa księstwa zostały wyrytowane i wydrukowane w Rzymie w warsztacie Giovanniego Battisty Cavalieriego w 1580 roku (zob. il. 1, s. 399) ${ }^{50}$. Cel tej publikacji był informacyjno-propagandowy i niewątpliwie inspirowany przez dwór, o czym świadczą towarzyszące jej inskrypcje i epigramat Tomasza Tretera, kolejnego sekretarza królewskiego, który właśnie wtedy przebywał w Rzymie.

Kochanowski mógł zaznajomić się $\mathrm{z}$ atlasem Pachołowieckiego już po napisaniu ody XII, ale mapy i plany z kampanii połockiej znajdowały się nie tylko w posiadaniu króla. Wiemy, że rysunki Pachoło-

narodowej (XVI-XX w.), red. Z. Karpus, W. Keemer, Toruń 1998, s. 17-43; idem, Kartografia Wielkiego Księstwa Litewskiego od XV do połowy XVIII wieku, Warszawa 2012, s. 60-61.

46 Zob. T. Kempa, Strubicz Maciej, w: Polski słownik biograficzny, t. 44, Kraków 2006-2007, s. 425-428.

${ }^{47}$ Por. K. Buczek, Dzieje kartografii polskiej..., s. 39-40; M. Korolko, Seminarium Rzeczypospolitej Królestwa Polskiego. Humaniści w kancelarii królewskiej Zygmunta Augusta, Warszawa 1991, s. 235.

48 Zob. Archiwum Jana Zamoyskiego, kanclerza i hetmana wielkiego koronnego, t. 1: 1553-1579, wyd. W. Sobieski, Warszawa 1904, s. 373.

49 Zob. J. Niedźwiedź, Atlas Księstwa Połockiego Stanisława Pachołowieckiego (1580). Propaganda, genologia i tworzenie wiedzy geograficznej, „Terminus” 19 (2017), z. 1 (42) (w oprac. red.); K. Łopatecki, Oblężenie i zdobycie warownej twierdzy połockiej przez Najjaśniejszego Króla Polski Stefana - analiza założeń taktycznych $w$ świetle źródeł kartograficznych, „Terminus 19 (2017), 3 (44) (w oprac. red.).

50 Zob. G. Franczak, Rzymski łącznik: Giovanni Battista Cavalieri (1525-1601), rytownik Hozjusza i Tretera, „Terminus” 19 (2017), z. 3 (44) (w oprac. red.). 
wieckiego i innych kartografów były już wcześniej powielane ręcznie i kolportowane. Pośrednim świadectwem jest cytowany wyżej list, gdzie mowa jest o robieniu kopii map dla Zamoyskiego, a bezpośrednim - wersja szkicu wykonana przez krakowskiego mistrza malarskiego Pawła Zumthorna, przechowywana obecnie w Dreźnie ${ }^{51}$. Rysunek drezdeński ukazuje ostatni etap oblężenia w dniu 29 sierpnia 1579 roku, przedstawiający m.in. ruchy wojsk, ostrzał armatni, pożary w Zamku Strzeleckim i zgliszcza Zapołocia ${ }^{52}$. O tym dniu przede wszystkim opowiada część narracyjna ody Kochanowskiego, zaś „umocnione żelazem wieże” („solidas adamante turres”, w. 92), to dwie wolnostojące, wysokie wieże artyleryjskie, znajdujące się wewnątrz każdego $\mathrm{z}$ dwóch zamków i dobrze widoczne na rysunku Pachołowieckiego i Zumthorna ${ }^{53}$.

Szczegóły przedstawione na mapach i planach wnoszą informacje, które niekiedy nie w są pełni zrozumiałe w relacjach $\mathrm{z}$ kampanii. Autorzy tych relacji przynajmniej częściowo zakładali, że ich czytelnicy będą się orientowali w topografii pogranicza litewsko-moskiewskiego, co mogło wynikać przede wszystkim z lektury map. Były to mapy niemal wyłącznie rękopiśmienne. Kilka ich kopii zachowało się do dzisiaj, m.in. mapa skopiowana przez Stanisława Sarnickiego przedstawiająca teatr działań wojennych w 1580 roku oraz kilka map wysłanych do Rzymu przez posłów papieskich i zachowanych do dziś w Archivo Secreto. Inna rękopiśmienna mapa trafiła w ręce sławnego kartografa Gerarda Mercatora i została wydana w jego atlasie z 1595 roku pt. Russiae pars amplificata. Przedstawia ona tereny, na których operowały oddziały Krzysztofa Radziwiłła „Pioruna” w 1581 roku. Nie można wykluczyć, że Kochanowski, pisząc Jezdę

51 Zob. S. Alexandrowicz, Źródła kartograficzne..., s. 33-34.

52 Wiele szczegółów dodaje kolorowany miedzioryt przedstawiający różne fazy oblężenia, a niezależny od rysunków Pachołowieckiego. Został on niewątpliwie oparty na rysunku jednego z uczestników oblężenia, a wydany przez Georga Macka w ulotnej gazecie niemieckiej, zob. S. Alexandrowicz, Źródła kartograficzne..., s. 39-42.

53 Por. ibidem, s. 39. 
do Moskwy o tej wyprawie, posłużył się innym wariantem tej mapy, dostarczonym mu z kancelarii królewskiej. Doskonale ilustruje ona jego poemat. Widać to, jeśli porówna się nazwy wymieniane przez polskiego poetę i niderlandzkiego kartografa (zob. il. 2, s. 400). Przypuszczalnie źródłem Kochanowskiego był rękopiśmienny diariusz sporządzony w kancelarii, którego uzupełnieniem była wspomniana mapa ${ }^{54}$. Trzy lata wcześniej rysunki Pachołowieckiego stanowiły dopełnienie tekstów narracyjnych, opisujących zdobycie Połocka. Przykłady Jezdy do Moskwy i mapy Mercatora, listów nuncjusza papieskiego uzupełnionych mapami oraz ulotnych gazet niemieckich z widokiem zdobywanego Połocka pokazują, że współwystępowanie literatury i kartografii w ówczesnej propagandzie polskiej było na porządku dziennym.

Podobne znaczenie jak mapy mają dla rozumienia tekstów połockich Kochanowskiego ówczesne chorografie i mapy charakteryzujące państwo moskiewskie. Trzy najistotniejsze, które mógł znać Kochanowski, to Tractatus de duabus Sarmatiis Macieja z Miechowa, Rerum Moschovitarum commentarii Zygmunta von Herbersteina i Sarmatiae Europeae descriptio Aleksandra Gwagnina ${ }^{55}$. Dostępne były też ogólne mapy Rosji sporządzone przez Paola Giovia, Antona Wieda, Giacoma Gastaldiego, Herbersteina oraz Antony'ego Jenkinsona ${ }^{56}$.

54 Przedstawiam tę kwestię w osobnym studium, omawiającym podobieństwa mapy Mercatora Russiae pars amplificata oraz Jezdy do Moskwy.

55 O wykorzystaniu w Polsce Herbersteina i Gwagnina: H. Grala, „Baro Geberstainu - człowiek wielki, zacny” i jagiellońscy dyplomaci. Wokół recepcji Rerum Moscoviticarum Commentarii w państwie polsko-litewskim, w: Многоликий и беспокойный славянский мир. Научный сборник к 50-летию Юрия Аркадьевича Борисёнка, ред. Г.Ф. Матвеев, Москва 2016, s. 27-41; G. Franczak, Faex gentium. Polacy w Moskwie wobec rosyjskiej „mniejszości”, w: Etniczność. Tożsamość. Literatura. Zbiór studiów, red. P. Bukowiec, D. Siwor, Kraków 2010, s. 55.

56 Zob. L. Bagrow, A History of the Cartography of Russia up to 1600, ed. by H.W. Castner, Wolfe Island, Ontario 1975, s. 61, 86-90, 98-104; G. Franczak, Asia or Europe? Some lies on where Russia lies: Writing and mapping the Muscovy in the $16^{\text {th }}$ Century (w druku). 
Pierwsza edycja traktatu Macieja z Miechowa wyszła w Krakowie w 1517 roku. Relacja Herbersteina, zaopatrzona w mapę, ukazała się długo po jego powrocie z państwa carów w 1549 roku. Obie książki cieszyły się niesłabnącym powodzeniem, o czym świadczą liczne przedruki w całej Europie oraz przekłady na języki wernakularne. Najświeższym jednak tekstem, dopiero co wytłoczonym w Krakowie w 1578 roku, była chorografia włoskiego oficera służącego w armii litewskiej, Aleksandra Gwagnina, Sarmatiae Europeae descriptio (wydanie polskie pt. Kronika Sarmacyi Europskiej wyszło w 1611 roku). Dzieło to pojawiło się na rynku księgarskim niewiele ponad rok przed napisaniem przez Kochanowskiego interesujących nas pieśni i ody, i od razu zyskało status bestselleru ${ }^{57}$ dzięki rzeczowości informacji, dobremu stylowi, a przede wszystkim chyba dzięki barwnemu opisowi okrutnych rządów Iwana Groźnego, stanowiącemu istotne dopełnienie charakterystyki państwa carskiego. Część poświęcona Moskwie nosi tytuł Kronika Wielkiego Księstwa Moskiewskiego $i$ państw do niego należących i zawiera cztery rozdziały: 1. Opisanie Księstwa Moskiewskiego i państw do niego należacych; 2. Religia moskiewska; 3. Obyczaje i zwyczaje moskiewskie; 4. Srogie i niestychane okrucieństwa Iwana Wasyliewicza, wielkiego kniazia moskiewskiego. Ten ostatni rozdział zdobył największy rozgłos. W istocie Gwagnin przywłaszczył w nim sobie relację Alberta Schlichtinga Sprawa wielkiego księcia moskiewskiego. Jednak to wersja Gwagnina stała się najbardziej znana, przynosząc włoskiemu pisarzowi (niezasłużoną) sławę ${ }^{58}$.

57 Do 1590 roku ukazało się pięć wydań, w tym przekład niemiecki i czeski. Por. S. Mund, Orbis Russiarum. Genèse et dévelopment de la représentation du monde „russe” en Occident à la Renaissance, Genève 2003.

${ }_{58}$ Zob. Tekst Schlichtinga krążył w Europie przede wszystkim w wersjach łacińskiej i niemieckiej, jednak jak wykazał Hieronim Grala, ich źródłem była wersja polskojęzyczna. Nie jest wykluczone, że za współautora Sprawy wielkiego księcia moskiewskiego należy uznać Macieja Stryjkowskiego - zob. H. Grala, Wokót dzieta $i$ osoby Alberta Schlichtinga (przyczynek do dziejów propagandy antymoskiewskiej $w$ drugiej połowie XVI w.), „Studia Źródłoznawcze” 38 (2000), s. 35-37, 42, 
Jeśli Kochanowski czytał Gwagnina (ewentualnie Schlichtinga), musiały go zainteresować przede wszystkim wiadomości z rozdziału pierwszego i czwartego. Mapowanie państwa rosyjskiego, podobne do Gwagninowego, znalazło się w Jeździe do Moskwy (1583), natomiast dla obu wierszy z początku 1580 roku istotny jest wizerunek okrutnego i groźnego Iwana:

On hardy, nieunoszony,

On tyran północnej strony,

Któremu, jako sam mniema,

Świat tak wielki równia nie ma.

P II $13,5-8$

Hoc ille Mavors ingenium viri,

Roburque, Moschus par animo pavens,

Primos ad armorum susurros,

Praesidiis trepidas per urbes.

O XII $25-28$

Poeta nie tłumaczy, dlaczego Iwan jest groźnym tyranem, zakładając wspólną wiedzę czytelników zainteresowanych tematyką moskiewską, ze zgrozą powtarzających relacje, które znalazły miejsce również w Descriptio Gwagnina:

48; A. Kappeler, Ivan Groznyj..., s. 55-56. W Polsce tekst Szlichtynga był też niekiedy wykorzystywany bez pośrednictwa Gwagnina. Por. G. Franczak, Wstęp, w: W. Neothebel, Acrostichis własnego wyobrażenia kniaża wielkiego moskiewskiego, oprac. G. Franczak, Warszawa 2016, s. 13-19. O europejskiej karierze tekstu Schlichtinga świadczą liczne jego kopie, warianty i tłumaczenia zachowane w wielu krajów. Tekst ten w dużym stopniu przyczynił się do upowszechnienia wśród włoskich elit negatywnych opinii o Iwanie Groźnym, zob. Por. И.В. Дубровский, Новые документы о России Ивана Грозного, „Русский сборник. Исследования по истории России" 11 (2012), s. 26-41; idem, Новые документы по истории отношений России и Италии при Иване Грозном, „Русский сборник. Исследования по истории России" 14 (2013), s. 7-12; idem, Латинские рукописи сочинений Альберта Шлихтинга, „Русский сборник. Исследования по истории России" 18 (2015), s. 74-217. 
Kiedy Litwini znienacka zdobyli bardzo obronny zamek zwany Borsko, pojmali w nim wojewodę i jego żonę, których jako jeńców wysłali do króla polskiego. Niedługo później wielki książę wykupił ich, oddając w zamian pewnego ważnego szlachcica polskiego. Kiedy przybyli do Moskwy, na rozkaz księcia zostali porwani w celu ukarania wraz z dwoma innymi szlachcicami moskiewskimi. A zatem na środku dziedzińca zostały ustawione trzy drzewce. Przewiązawszy ich w pasie, zawieszono na linach. Książę wraz $\mathrm{z}$ synem strzelając do nich z łuków, przeszywał ich strzałami i mówił przemyślnie: „O dzielni obrońcy, tak powinniście mnie i moich zamków bronić!”. Potem tłum dworzan wzorem księcia tak ich naszpikował strzałami, że z powodu liczby strzał, [skazańców] nie było widaćs9.

Podobnych popisów okrucieństwa nad własnymi poddanymi i jeńcami cara Gwagnin podał o wiele więcej. Włączenie przez Gwagnina rozdziału o Iwanie może się wydawać dziwne, gdyż w pozostałych częściach swojego traktatu unika nawiązań do bieżących wydarzeń politycznych w opisywanych przez siebie krajach. Wyraźnie widać w nim próbę nagłośnienia zbrodni Iwana Groźnego. Jeśli weźmiemy pod uwagę, że utwór ukazał się tuż przed kampanią połocką Batorego, publicystyczny fragment dyskredytujący cara już nie wydaje się taki dziwny. Pytanie Cui prodest? sugeruje inspirację króla i kancelarii. Sarmatiae Europeae descriptio stanowi więc jeden $\mathrm{z}$ istotniejszych tekstów łacińskich, które miały się w przyszłości przyczynić do propagandowego zwycięstwa Rzeczypospolitej nad Moskwą. Działania strony polskiej były po części uprzedzeniem, a po części odpowiedzią na intensywne akcje propagandowe czynione przez Iwana Groźnego ${ }^{60}$. O tych działaniach Zamoyski i jego ludzie z kancelarii dobrze wiedzieli (o czym jeszcze będzie niżej). Znał je również Kochanowski.

59 A. Guagnini, Sarmatiae Europeae descriptio, Kraków 1578, k. 45r., przeł. J. Niedźwiedź.

60 Zob. А.И. Филюшкин, Изобретая первую войну России и Европы. Балтийские войны второй половины XVI века глазами современников и потомков, Санкт-Петербург 2013, s. 98-101. 
Poeta piszący o „hardym, nieunoszonym tyranie północnej strony”, a gdzie indziej nazywający go trux hostis, przywołuje obraz Iwana Groźnego, który już wcześniej został utrwalony w tekstach Schlichtinga, Gwagnina i Neothebla ${ }^{61}$ i jest jednym z aktywnych uczestników wojny propagandowej kancelarii polskiej z moskiewską.

\section{Dokumenty kancelaryjne}

Mimo że od ok. 1570 roku Kochanowski nie służył na dworze, nadal podpisywał się tytułem sekretarza Jego Królewskiej Mości. O tym, że nie skończył definitywnie swojej przygody z kancelarią, świadczyłyby owe styczniowe poselstwa do poety i inne liczne zlecenia, które dawał mu Zamoyski. Można jednak odnieść wrażenie, że związki te były głębsze i że Kochanowski miał wgląd w sprawy kancelarii królewskiej, a przynajmniej tej jej części, która była odpowiedzialna za propagandę.

W polskiej pieśni $O$ wzięciu Połocka poeta sygnalizuje taką wiedzę o Iwanie Groźnym, której nie znajdziemy w żadnej z kronik i chorografii. Zarzuca mianowicie „carowi moskiewskiemu”, iż ten „jako sam mniema, / Świat tak wielki równia nie ma” (w. 8-9), dalej przestrzega go: „hardzie nie każ!” (czyli: nie wypowiadaj się butnie, w. 21) i przytacza jego słowa:

Teraz był czas prorokować,

Komu szłyk naprzód zdejmować;

Teraz się było dowiadać,

Kto ma naprzód $\mathrm{z}$ konia spadać.

P II 13, 21-24

Na pozór wygląda to na konwencjonalną prozopopeję wynikającą z licentia poetica i fantazji poety, skąd bowiem Kochanowski mógłby

${ }^{61}$ Zob. G. Franczak, Wstęp..., s. 18. 
wiedzieć o pogróżkach i sądach, które Iwan miałby wygłaszać przeciw Stefanowi Batoremu? Jakby tego było mało, we fragmencie późniejszej o trzy lata Jezdy do Moskwy poeta znów powtarza twierdzenia Moskali, którym z ironią zarzuca kompletną ignorancję w dziedzinie historii. Według Kochanowskiego Iwan Groźny uzurpuje sobie bowiem prawo do bycia potomkiem cesarza rzymskiego ${ }^{62}$. Jednak to nie wyobraźnia poetycka kazała poecie wkładać takie słowa w usta Iwana Groźnego. Podstawą były dla niego propagandowe pisma wysyłane do Włoch i krajów niemieckich, ale też do króla polskiego ${ }^{63}$.

Pismo (gramota) z 1581 roku, które car przysłał do polskiego i litewskiego władcy, zostało omówione przez jednego z ówczesnych sekretarzy królewskich, księdza Jana Piotrowskiego, który pozostawił po sobie obszerną relację z oblężenia Pskowa złożoną z listów do marszałka wielkiego koronnego Andrzeja Opalińskiego:

Pan kanclerz biedzi się nad listem moskiewskim; próżno, aby mu pisarze zdołać umieli, jest go 12 arkuszy całych. A cóż ja wiem, czego w nim nie masz. Argumenta dziwne, łajanie sprosne, już tam przeczyta królowi krzywoprzysięstwo, bisurmaństwo, dosyć uszczypliwie. Naterminował był król, jakoby mu odpisować, krótko eksprobując [wyrzucając] mu niecnoty jego. Chce mu posłać dwoje księgi pisane o obyczajach jego od cudzoziemców: Gwanina, jednego Włocha, a drugie Krancjusza, dając mu znać, że wszytek świat pełen jego niecnót ${ }^{64}$.

62 „Czwartynasty potomek rzymskiego cesarza / Augusta; któż wie, gdzie wziął tego kronikarza!” (J 75-76). Doktryna o rzymskim pochodzeniu carów moskiewskich została upowszechniona w czasach Iwana Groźnego. Według Powieści o kniaziach włodzimierskich i innych utworów moskiewskich z XVI wieku ruska dynastia Rurykowiczów wywodziła się od Prusa, brata Oktawiana Augusta. Prus z polecenia brata miał panować na terenach rozciągających się od Gdańska do Niemna. Od jego imienia kraina ta wzięła nazwę Prus. Jednym z potomków Prusa był książę Ruryk, poproszony przez Nowogrodzian do panowania nad ich księstwem. Zob. A. Musin, "Ród ruski”, „ród wareski” i narodowość staroruska „Orientalia Christiana Cracoviensia" 4 (2012), s. 13.

63 Zob. А. И. Филюшкин, Изобретая первую войну России и Европьљ.., s. $178-191$.

${ }^{64}$ J. Piotrowski, Dziennik wyprawy Stefana Batorego pod Psków, wyd. A. Czuczyński, Kraków 1894, s. 33. 
$\mathrm{W}$ istocie to nie pan kanclerz biedził się nad listem, gdyż polecił go sekretarzom, którzy musieli przełożyć go na łacinę (król nie znał ruskiego, a i z polskim sobie nie radził), a następnie przygotować odpowiedź, co nie było prostą rzeczą z powodu dotkliwego zimna, przed którym nie najlepiej chroniły namioty kanclerskie. Piotrowski z radością odnotował zakończenie prac nad odpowiedzią dla Iwana i z satysfakcją pisał o załącznikach: „Do tego tyżeśmy Moskiewskiemu posłali Herbersteina, Guaninum i kilka capitula ex Crancio [rozdziałów z Krancjusza] po łacinie, aby sobie czytał, co o jego obyczajach świat pisze" 65 .

Piotrowski oprócz Herbersteina i Gwagnina wymienia Krancjusza (Alberta Krantza, 1448-1517), którego dzieło Wandalia, wydane po raz pierwszy w 1519 roku i wznowione w 1575 roku z uzupełnieniami, zawierało szereg niepochlebnych opinii o Moskwie oraz Iwanie. Jak widać, pan kanclerz nakazał swoim podwładnym zabranie ze sobą na wyprawę wojenną całkiem sporej biblioteki (wspomniane księgi są pokaźnych rozmiarów) i jak się okazało, uczynił to w konkretnym celu: by wykorzystywać je w wojnie propagandowej. Przesłanie odpowiednich fragmentów tych traktatów księciu moskiewskiemu jest zatem niczym innym, jak demonstracją polsko-litewskiej potęgi propagandowej: Batory i Zamoyski przestrzegają Iwana, że w pozyskiwaniu sobie europejskiej opinii publicznej mają przewage i że są w stanie osiągnąć o wiele więcej niż propaganda moskiewska.

Oba teksty Kochanowskiego z 1580 roku bardzo dobrze wpisują się w wykorzystanie literatury przez Zamoyskiego i jego kancelarię. Są one zbieżne nie tylko $\mathrm{z}$ dostępnymi chorografiami i kronikami, pozostającymi pod wpływem polityki propagandowej kancelarii królewskiej, ale również z diariuszami i relacjami kancelaryjnymi (co widać w Jeździe do Moskwy i w Odzie XII), a przede wszystkim nawiązują wprost do listów Iwana Groźnego. Kochanowski dobrze się orientuje, jaka jest ich zawartość, wie, jakie car ma roszczenia i jaką retoryką strachu posługuje się w stosunku do króla polskiego.

65 Ibidem, s. 44. 


\section{Historiografia i poezja}

Osobami odpowiedzialnymi w kancelarii za propagandę w czasie pierwszej wojny moskiewskiej byli między innymi dwaj bliscy współpracownicy kanclerza, Reinhold Heidenstein i Krzysztof Warszewicki, prowadzący „polowe biuro prasowe”, w którym drukowali gazety ulotne ${ }^{66}$. Heidenstein (1553-1620) odbył podobną ścieżkę edukacyjną co Kochanowski i Zamoyski, przede wszystkim dzięki studiom w Padwie. Natychmiast po powrocie z Włoch, a było to w październiku 1579 roku, czyli zaraz po zakończeniu kampanii połockiej, został zatrudniony przez Zamoyskiego, na którego zlecenie tuż po zakończeniu wojen moskiewskich napisał dzieło historyczne De bello Moscovitico commentatorium libri sex (Kraków 1584), opisujące całość zmagań z lat $1579-1582^{67}$.

Dla łacińskiej ody Kochanowskiego traktat ten stanowi istotny kontekst z jednego ważnego powodu - historyk, podobnie jak poeta, nie widział oblężenia Połocka, a mimo to szczegółowo je opisał, opierając się na źródłach dostarczonych mu przez Zamoyskiego ${ }^{68}$. Wynikałoby z tego, że obaj padewczycy korzystali jeśli nie z tych samych narracji, to $\mathrm{z}$ bardzo podobnych. Znamy zresztą kilka innych relacji z oblężenia (m.in. jej uczestnika Joachima Bielskiego ${ }^{69}$ oraz Macieja Stryjkowskiego, a także relacje włoskie, np. Antonia Marti-

${ }_{66}$ Por. J. Nowak-Dłużewski, Okolicznościowa poezja polityczna w Polsce. Pierwsi królowie elekcyjni..., s. 231.

67 Utwór ten został z niewielkimi zmianami włączony do rozleglejszego opracowania historycznego Heidensteina Rerum Polonicarum ab excessu Sigismundi Augusti libri XII wydanego po raz pierwszy we Frankfurcie nad Menem w 1672 roku. Korzystam tu z polskiego tłumaczenia: R. Heidenstein, Pamiętniki wojny moskiewskiej w 6 ksieggach, przeł. J. Czubek, Lwów 1894. Por. D. Kupisz, Połock 1579..., s. 5-6.

68 Zob. D. Kupisz, Połock 1579..., s. 5-6.

69 Bielski dołączył ją do kolejnego wydania kroniki swojego ojca, Marcina. Por. M. Bielski, Kronika polska, t. 3, wyd. K.J. Turowski, Sanok 1856, s. 1447-1454. 
nellego $^{70}$ ), z których jedna jest wyjątkowo interesująca, gdyż wywodzi się wprost z kancelarii królewskiej. To Edictum regium de supplicationibus ob captam Polociam datowana na dzień po kapitulacji Połocka, czyli na 31 sierpnia 1579 roku $^{71}$. Można założyć, że między innymi ten dokument przywiózł Kochanowskiemu posłaniec pana kanclerza 6 stycznia 1580 roku.

Lektura tych relacji pozwala na wyciągnięcie istotnego wniosku: narracja Kochanowskiego jest precyzyjna. Oczywiście Heidenstein poprzez zastosowanie prozatorskiej, kronikarskiej formy może sobie pozwolić na większą szczegółowość i kompletność, ale nawet na tle jego kroniki walory informacyjne ody XII są niezaprzeczalne. Poniekąd cel obu autorów jest więc zbieżny: opowiedzieć o sierpniu 1579 roku. Oda XII relacjonuje przede wszystkim ostatnie dwa dni oblężenia (29-30 sierpnia), aczkolwiek opis zmagań zaczyna się od opowiedzenia o reakcji Iwana Groźnego na wieść o koncentracji wojsk królewskich kilka miesięcy wcześniej - w twierdzach umieścił załogi, sam zaś usunął się w głąb swojego państwa (w. 25-32).

Kochanowski poświęca dużo miejsca początkowym trudnościom oblegających, związanym po pierwsze z silnymi fortyfikacjami miasta, któremu pomagało ponadto dobre położenie (w. 55), po drugie z dzielną postawą załogi (w. 56 i 86) i po trzecie z nieustającymi deszczami (w. 57-60 i 63-64). Wszystkie te trzy przyczyny znajdujemy $\mathrm{w}$ relacjach $\mathrm{z}$ oblężenia:

1) Zamek nazywany przez nas średnim, wznosi się na pagórku, z którego rozległy roztacza się widok; broniła go od południa Dźwina [...], od północy i zachodu rzeka Połota i miasto Zapołocie, od wschodu Zamek Strzelecki, naokoło zaś spadziste boki góry, na które się wznosił, a wreszcie głęboki

70 A. Martinelli [A. Мартинелли], История взятия Полоцка польским королем Стефаном Баторием в 1579 году. Предисловие, подготовка текста и перевод И. В. Дубровский, „Русский сборник. Исследования по истории России" 21 (2017), s. 7-100.

${ }^{71}$ Edictum regium de supplicationibus ob captam Polociam, w: Relacje nuncjuszów apostolskich $i$ innych osób o Polsce od roku 1548 do 1690, t. 1, wyd. E. Rykaczewski, Berlin 1864, s. 317-320. 
rów i wał, na których umocnienie wysiliła się sztuka wojenna; miał też bardzo silne ściany i baszty, zbudowane $\mathrm{z}$ kilku pokładów potężnych tramów dębowych powiązanych pomiędzy sobą ${ }^{72}$.

2) Moskwa nie tylko więc naszych odparła i zmusiła do odwrotu tą samą drogą przez płomienie, którą niebacznie przybyli, ale nawet powodzeniem rozzuchwalona puściła się dalej za nimi w pogoń, rażąc z tyłu strzałami ${ }^{73}$.

3a) Ostenderat vi sua praepotens Deus, in manu sua rerum gerendarum potestatem esse et assiduas pluvias pluribus diebus inta immiserat, ut et operae militum maiorem in modum impedierentur et oppugnandi ratio etiam atque etiam retardaretur ${ }^{74}$.

3b) Słoty te i wzniecenia pożaru utrudniały i tak dalece zalały wszystkie rowy i ziemię, iż żołnierz niemal nigdzie nogą pewnie stanąć nie mógł. ${ }^{75}$

Kiedy Kochanowski pisze, że ziemia nie mogła utrzymać ciężaru armat ani oddziałów królewskich (w. 63-64), przetwarza źródło, z którego korzystał też Heidenstein:

Drogi wskutek ulewnych i ciągłych deszczów tak były popsute, iż konie pociągowe, nie mogąc się z błota wydobyć, bardzo często przy wozach padały i na wszystkich drogach pełno było ścierw końskich ${ }^{76}$.

Na próżno „straszne armaty” („incredibili tormentorum vi”77) wyrzucały „kule ogniste” (w. 66-67):

72 R. Heidenstein, Pamiętniki..., s. 54.

73 Ibidem, s. 66.

74 Edictum regium..., s. 318-319.

75 R. Heidenstein, Pamiętniki..., s. 60. Por. D. Kupisz, Połock 1579..., s. 138.

76 R. Heidenstein, Pamiętniki..., s. 60-62. W analogiczny sposób pisze Joachim Bielski: „Do tego drogi złe padły tak, iże trudno było co wozić, bo ziemia (która tam jest tłusta i glinna) prawie była rozkisiała, że i pod namioty suchego nigdziej miejsca nie było, także konie nasze ledwie z błota wychodziły; przeto ich barzo wiele wszędzie po drogach leżało zdechłych, które też i od głodu częścią zdechały, bochmy je aż na ostatek lasem żywili, co trawy skąpo było, a owsa nie pytaj, którego beczkę (gdy się skąd trafił) po dziesiąci złotych płacono”, M. Bielski, Kronika polska..., s. 1450.

77 Edictum regium..., s. 319. 
Bekiesz począł naprzód z dział walić w zamek, lecz to niewiele skutkowało, gdyż kule zamiast burzyć parkan drewniany, dziurawiły go tylko w pewnych miejscach; wzięto się więc do kul ognistych ${ }^{78}$.

Wreszcie, jak pisze poeta, niebo staje się łaskawsze, różowy poranek jest złą wróżbą dla oblężonych (w. 69-72), o czym wspomina też Edictum regium:

Respexit vero tandem nos sua benignitate clementissimus Deus concessitque, ut quae prima nobis paulo serenior dies vicesima nona Augusti illuxit ${ }^{79}$.

29 sierpnia rozpoczął się szturm: „wtedy - według Kochanowskiego - przy jasnym słońcu, wypełniona ogniem kula podpala twierdzę, w wielu miejscach nieoczekiwanie zajaśniał płomień” (w. 74-76):

ea incendium a milite nostro arci latum sit, cum contentione atque discrimine, cum se miles noster in fossas demittere et Polottam flumen superare denique arduum clivum cui impositum erat propugnaculum, subiere et manibus materiam ignemque inter infestissima creberrimaque hostium tela, inferre necesse haberet: quod incenium cum vehementius exarcisset et munitionis anterioris aditum aliquem patefecisset ${ }^{80}$.

Kochanowski, nie wdając się w szczegóły, kontynuuje opisywanie „dopiero późną nocą przerwanych walk” (w. 87), o czym Heidenstein wspomina tak:

Ponieważ się już ściemniać poczynało, osądzono przeto za rzecz i trudną, i niebezpieczną drapać się $\mathrm{w}$ górę po tak spadzistym stoku i przedzierać przez płomienie (...). Noc wreszcie uciszyła ten rozruch ${ }^{81}$.

Można by przytoczyć o wiele więcej zbieżności między relacjami prozatorskimi a narracją z ody XII - każdy wers i każda linijka ma

\footnotetext{
78 R. Heidenstein, Pamiętniki, s. 58. Por. D. Kupisz, Połock 1579..., s. 133.

79 Edictum regium..., s. 319.

80 Ibidem. Por. D. Kupisz, Połock 1579..., s. 143-144.

81 R. Heidenstein, Pamiętniki..., s. 65-66.
} 
na celu rozwijanie opowieści o ostatnich dwóch dniach oblężenia. Jak widać, Kochanowski wiernie, choć w sposób syntetyczny, trzyma się faktografii, podobnie zresztą jak w późniejszej Jeździe do Mos$k w y^{82}$.

Są jednak pewne odstępstwa. Pierwsza „nieścisłość” pojawia się $\mathrm{w}$ momencie, kiedy armia Batorego wkracza na terytorium wroga. Celem wyprawy był Połock, więc zdobywający nie kusili się o obleganie mniejszych zamków i zostały one zajęte dopiero po kapitulacji twierdzy (zamki te zostały przedstawione przez Stanisława Pachołowieckiego). Kochanowski jednak w swoim tekście za pomocą poezji porządkuje rzeczywistość: całe nadgraniczne terytorium wroga zostało podbite, zrównane z ziemią ogniem i mieczem (w. 41-44) zaraz po wkroczeniu wojsk litewsko-polsko-węgierskich, a tylko główny gród Księstwa Połockiego wciąż się bronił. Podbijanie tych terenów oraz niesłychane okrucieństwa wojny unaocznia Heidenstein:

Nastąpiła straszna, powszechna rzeź, tak iż wielu żołnierzy, a między nimi Wejher, stary rotmistrz, nie wahali się twierdzić, że w wielu bitwach walczyli, ale na żadnym pobojowisku nie widzieli takich stosów trupów, co tutaj. [...]

Tak samo i Filon Kmita, starosta orszański, mając od króla kilka chorągwi jazdy, zbiera z pobliskich ziem liczną drużynę ochotników i wpada w kraj nieprzyjacielski. Spaliwszy do tysiąca wsi i aż po Smoleńsk się zapędziwszy, gołą tylko ziemię za sobą zostawi1 ${ }^{83}$.

82 Przykłady polsko- i łacińskojęzycznych utworów Kochanowskiego poświęconych wojnie z Moskwą są sobie bliskie w sposobie ich tworzenia i komplementarne. Wiersze te nie pasują w związku z tym do zasadniczo słusznej tezy Wiktora Weintrauba, w której wskazywał na duże różnice w sposobie ujmowania tych samych spraw w wierszach polskich i łacińskich (jak panowanie Henryka Walezego w Polsce lub pochwała kobiety). Zob. W. Weintraub, Jan Kochanowski $i$ Joannes Cochanovius: dwóch świadków historii, w: Dzieło literackie jako źródło historyczne, red. Z. Stefanowska, J. Sławiński, Warszawa 1978, s. 146-165.

${ }^{83}$ Ibidem, s. 77 i 82 . O spustoszeniach wspomina też oficjalna relacja z kancelarii: „Interea a copiis nostris quae processerunt, arces tres, Cosiana, Crasna et Sithana per excursionem celeriter occupatae et incendio deletae sunt", Edictum regium..., 
Tyle tylko, że zdarzenia opisane przez historyka Heidensteina miały miejsce już po zdobyciu Połocka. Tymczasem dla poety Kochanowskiego p r a w d z i w i e j wyglądała wojna, w której główna twierdza stanowiła ostateczny punkt obrony, a jego zdobycie było kulminacją wojny i najwyższą chwałą zwycięskiego władcy.

\section{Zakończenie, czyli ponownie poezja}

Oda o zdobyciu Połocka jest utworem oficjalnym i tekstem władzy. Kochanowski spędzający zimę $\mathrm{w}$ odsuniętym od centrów politycznych Czarnolesie, do którego usunął się dziesięć lat wcześniej, uciekając jakoby od dworu i literatury oficjalnej, nadal uczestniczył $\mathrm{w}$ grach związanych $\mathrm{z}$ władzą. Przypuszczalnie nie tylko na skutek nacisków kanclerza. Cztery wiersze napisane dla Zamoyskiego w styczniu 1580 roku nie stanowią przecież wyjątku w jego późnej twórczości, mocno osadzonej w ówczesnym życiu publicznym.

Wciąż zatem pozostajemy w obrębie dyskursu politycznego. Dokumenty, którymi z dużym prawdopodobieństwem mógł się posługiwać Kochanowski i które przytoczyłem w niniejszym artykule, są w przeważającej większości (jeśli nie wszystkie) również tekstami oficjalnymi: to listy, mapy, kroniki, diariusze, ody Horacego i innych poetów propagandowych lub wchodzących do spisu obowiązkowych lektur szkolnych. Teksty te, czyli ślady tamtych czasów, będące w istocie tylko okruchami, które dotrwały do dzisiaj, są jednostronne, więc umożliwiają nam tylko jeden sposób zrozumienia, jakie były okoliczności powstania tego wiersza.

Lecz Kochanowski, będący jednym $z$ architektów oficjalnego dyskursu ówczesnej władzy wciąż pozostaje poetą, a jego tekst nie jest przewierszowaniem faktów. Wspomniałem wyżej, że porządek

s. 318. Notabene Kochanowski w Jeździe do Moskwy nadmienia o systematycznym paleniu wsi przez oddziały Radziwiłłowskie: „Dworów i wsi kilkaset w popiół obrócono" (J 288). 
wydarzeń został na nowo ułożony przez poetę, aby wyglądały one „prawdziwiej”. Co więcej, wprowadził on pewne kłopotliwe dodatki, które czytelnikom i badaczom z XIX i XX wieku wydają się zwykle pseudoerudycją i obciążeniem tekstu. To jest to, co historycy literatury nazywają retorycznym i „mitologicznym balastem”. Poeta mógłby przecież pisać konkretnie i zrezygnować z peryfraz oraz imion mitologicznych. Na przykład w wersach 61-64 przywołane zostały argumenty zaczerpnięte z Edictum regium o ingerencji Boga spowalniającej oblężenie nadmiernymi deszczami. Poeta wprowadził tam Jowisza zmagającego się z Wulkanem, czyli niebo walczące z ziemią i wodę z ogniem. Zwykle Kochanowski kondensuje wydarzenia opisywane w przytoczonych narracjach prozatorskich. Widać, że bardzo zależy mu na ekonomii słowa i że każde określenie, fraza, epitet są starannie zaplanowane i mają swoje precyzyjne znaczenie. Jowisze i Mulcybery wyglądają więc na wyjątkową rozrzutność.

Odpowiedź na tę wątpliwość znajduje się w ówczesnym pojmowaniu poezji. Otóż o poetyckości nie decyduje zastosowanie metrum poetyckiego i zastąpienie rytmiczności prozatorskiego okresu retorycznego rytmicznością trochejów, chorijambów i jambów; istotna jest zmiana dyskursu $\mathrm{z}$ faktograficznego na symboliczny: zdarzenia stają się znakami i uogólnieniami, mówią o prawdzie, ale nie w sensie jednostkowego zdarzenia. Dlatego ogień kul armatnich gaszonych przez deszcz jest starciem dwóch żywiołów i dwóch bogów, a także niepojętym zrządzeniem Opatrzności.

Jak wspomniałem, Kochanowski jako poeta dokonuje syntezy. W poezji lirycznej nie ma miejsca na epicki rozmach, to oczywiste, ale z drugiej strony zadaniem poety (jakby to określili za Arystotelesem Minturno czy Scaliger) jest uogólnienie i w poetyckim naśladowaniu uchwycenie istoty rzeczy, zwykle kosztem szczegółów i prawdy właściwej realistycznej narracji historycznej. Tym się różni poezja od historiografii ${ }^{84}$. W odzie XII Kochanowskiemu udała się jednak

84 Por. J. Domański, Dlaczego poezja jest bardziej filozoficzna od historii? Glosa do dziewiątego rozdziału Poetyki Arystotelesa, „Przegląd Filozoficzny” 1992, nr 2, s. 5-8. 
trudna sztuka uchwycenia równowagi, która realizuje się zarazem w doborze faktów i ich uogólnianiu, jak i w prowadzeniu szczegółowej opowieści o rzeczywistych wydarzeniach, w której niemal każde słowo wnosi nową informację. Taki eksperyment mógłby wzbudzać zarzuty z punktu widzenia ówczesnej poetyki: jak na historiografię oda De expugnatione Polottei jest w zbyt małym stopniu faktograficzna, jak na poezję - w zbyt małym stopniu korzysta z prawdopodobieństwa kosztem prawdy. Jednakże tak pomyślana opowieść o czynach Batorego i jego armii pozwala wykroczyć jej poza narrację historyczną i poza dobrze dotychczas wydeptaną ścieżkę łacińskiej poezji. W ten sposób staje się mocnym zwieńczeniem Lyricorum libellus ${ }^{85}$, będącego poetyckim rozważaniem nad siedmioletnim „klimakterem" Rzeczypospolitej: od oczekiwania na przybycie Henryka Walezego aż do wielkiego triumfu jego następcy. Jest jednak również poetyckim i filozoficznym (jeśli posłużylibyśmy się tu znanymi Kochanowskiemu kategoriami Arystotelesowskimi) uogólnieniem na temat zasad właściwego sprawowania władzy i Opatrzności boskiej.

Potraktowanie ody jako nie tylko przekazu politycznego, ale również wiersza, pozwala na poszerzenie jej interpretacji i wyjście poza narzucony przez inne źródła porządek czytania. Wciąż jednak ta interpretacja jest ograniczona i zdeterminowana przez choćby niemożność przysłuchania się rozmowom toczonym wokół ody Kochanowskiego w roku 1579 i 1580 . Wciąż jest to opowieść o tekstach, które się zachowały, nie zaś wejście w świat, w którym zmęczony poseł kanclerza dociera wieczorem do pałacu w Jazdowie pod Warszawą, aby dostarczyć list i wiersze pana Kochanowskiego z Czarnolasu.

${ }^{85}$ Por. J. Glomsky, Historiography as Art..., s. 145-146 i 150-152; Z. Głombiowska, Koncepcja cyklu w polskich i łacińskich utworach Jana Kochanowskiego, Gdańsk 1980. 


\section{Bibliografia}

Alexandrowicz S., Nowe źródło ikonograficzne do oblężenia Połocka w 1579 r., „Kwartalnik Historii Kultury Materialnej” 19 (1971), nr 1.

Alexandrowicz S., Źródła kartograficzne do wyprawy połockiej Stefana Batorego roku 1579, w: Od armii komputowej do narodowej (XVI-XX w.), red. Z. Karpus, W. Keemer, Toruń 1998.

Alexandrowicz S., Kartografia Wielkiego Księstwa Litewskiego od XV do połowy XVIII wieku, Warszawa 2012.

Archiwum Jana Zamoyskiego, kanclerza i hetmana wielkiego koronnego, t. 1: 15531579, wyd. W. Sobieski, Warszawa 1904

Awianowisz B., Wstęp, w: E. Pielgrzymowski, Apostrofa panegiryczna, oprac. i przeł. B. Awianowicz, Warszawa 2012.

Bagrow L., A History of the Cartography of Russia up to 1600, ed. by H.W. Castner, Wolfe Island, Ontario, 1975

Basilius Hyacinthius Vilnensis, Panegyricus in excidium Polocense..., Padova 1580.

Benedict Ph, Graphic History. The Wars, Massacres and Troubles of Tortorel and Parrissin, Genève 2007.

Bielski M., Kronika polska, t. 3, wyd. K.J. Turowski, Sanok 1856.

Brennan M., Literary Patronage in the English Renaissance: The Pembroke Family, London - New York 1988.

Brożek M., Ambicje improwizatorskie poetów polsko-łacińskich XVI w., w: Łacińska poezja w dawnej Polsce, red. T. Michałowska, Warszawa 1995.

Buchwald-Pelcowa P., Dawne wydania dzieł Jana Kochanowskiego, Warszawa 1993.

Buczek K., Dorobek kartograficzny wojen Stefana Batorego „Wiadomości Służby Geograficznej” 1934, z. 3.

Buczek K., Dzieje kartografii polskiej od XV do XVIII wieku. Zarys analityczno-syntetyczny, Warszawa 1963.

Buczek K., Kartografia polska w czasach Stefana Batorego, Warszawa 1933.

Buszewicz E., Forma gatunkowa ody w łacińskiej poezji Jana Kochanowskiego, „Terminus" 16 (2014), z. 1 (30).

Čiurinskas M., Pergalès prie Oršos (1514) propaganda Europoje: šaltiniu apžvalga, literatūriniai bei kultūriniai aspektai, „Senoji Lietuvos Literatūra” 21 (2006).

Dantyszek J., Carmina, wyd. S. Skimina, Kraków 1950.

Domański J., Dlaczego poezja jest bardziej filozoficzna od historii? Glosa do dziewiatego rozdziału Poetyki Arystotelesa, „Przegląd Filozoficzny” 1992, nr 2.

Дубровский И.В., Новые документы о России Ивана Грозного, „Русский сборник. Исследования по истории России" 11 (2012). 
Дубровский И.В., Новые документы по истории отномений России и Италии при Иване Грозном, „Русский сборник. Исследования по истории России” 14 (2013).

Дубровский И.В., Латинские рукописи сочинений Альберта Шлихтинга „Русский сборник. Исследования по истории России” 18 (2015).

Edictum regium de supplicationibus ob captam Polociam, w: Relacje nuncjuszów apostolskich i innych osób o Polsce od roku 1548 do 1690, t. 1, wyd. E. Rykaczewski, Berlin - Poznań 1864.

Ferenc M., Mikołaj Radziwiłł „Rudy” (ok. 1515-1584). Działalność polityczna i wojskowa, Kraków 2008.

Филюшкин А.И., Изобретая первую войну России и Европы. Балтийские войны второй половины XVI века глазами современников и потомков, Санкт-Петербург 2013.

Franczak G., Asia or Europe? Some lies on where Russia lies: Writing and mapping the Muscovy in the $16^{\text {th }}$ Century (w druku).

Franczak G., Faex gentium. Polacy w Moskwie wobec rosyjskiej „mniejszości”, w: Etniczność. Tożsamość. Literatura. Zbiór studiów, red. P. Bukowiec, D. Siwor, Kraków 2010.

Franczak G., Rzymski łączik: Giovanni Battista Cavalieri (1525-1601), rytownik Hozjusza i Tretera, „Terminus” 19 (2017), z. 3 (44).

Franczak G., Wstęp, w: W. Neothebel, Acrostichis własnego wyobrażenia kniaża wielkiego moskiewskiego, oprac. G. Franczak, Warszawa 2016.

Dmitruk K.M., Wokót teorii i historii mecenatu, w: Z dziejów mecenatu kulturalnego $w$ Polsce, red. J. Kostecki, Warszawa 1999.

Glomsky J., Historiography as Art: Jan Kochanowski's „Lyricorum libellus” (1580), w: Renaissance Culture in Context. Theory and Practice, ed. by J.R. Brink, W.F. Genturp, Aldershot - Brookfield 1993.

Glomsky J., Patronage and Humanist Literature in the Age of the Jagiellons. Court and Career in the Writings of Rudolf Agricola Junior, Valentin Eck and Leonard Cox, Toronto - Buffalo - London 2007.

Głombiowska Z., Koncepcja cyklu w polskich i łacińskich utworach Jana Kochanowskiego, Gdańsk 1980.

Głombiowska Z., Łacińska oda Jana Kochanowskiego o zdobyciu Połocka. Tekst i komentarz, „Studia Classica et Neolatina” 9 (2010).

Głombiowska Z., O pindaryzmie Epinicionu Jana Kochanowskiego, w: Jan Kochanowski. Interpretacje, red. J. Błoński, Kraków 1989.

Grala H., „Baro Geberstainu - człowiek wielki, zacny” i jagiellońscy dyplomaci. Wokół recepcji Rerum Moscoviticarum Commentarii w państwie polsko-litewskim, w: Многоликий и беспокойный славянский мир. Научный сборник к 50-летию Юрия Аркадьевича Борисёнка, ред. Г.Ф. Матвеев, Москва 2016. 
Grala H., Jeńcy spod Orszy: między jagiellońska „propaganda suckesu” a moskiewskq racja stanu (1514-1552), w: Aetas media - aetas moderna. Studia ofiarowane profesorowi Henrykowi Samsonowiczowi w siedemdziesiąta rocznicę urodzin, Warszawa 2000.

Grala H., Wokół dzieła i osoby Alberta Schlichtinga (przyczynek do dziejów propagandy antymoskiewskiej $w$ drugiej połowie XVI w.), „Studia Źródłoznawcze” 38 (2000).

Guagnini A., Sarmatiae Europeae descriptio, Kraków 1578.

Heidenstein R., Pamiętniki wojny moskiewskiej w 6 księgach, przeł. J. Czubek, Lwów 1894.

Helgerson R., The Land Speaks: Cartography, Chorography, and Subversion in Renaissance England, w: Representing the English Renessance, ed. by S. Greenblatt, Berkeley 1988.

Hermann D., Musae Marti coniunctae. Ex regiis ad captam Polociam castris missae clarissimo viro doctori Jacobo Monaw, Vratislaviensi et ornatissimae viduae Susannae natae in honestissima familia Voglovium novis sponsis, Wilno 1579.

Janicki M., Obraz Bitwa pod Orsza - geneza, datowanie, wzory graficzne a obraz bitwy „na Kropiwnej” i inne przedstawienia batalistyczne w wileńskim pałacu Radziwiłłów, w: Bitwa pod Orsza, red. M. Nagielski, Warszawa 2015.

Kappeler A., Ivan Groznyj im Spiegel der ausländischen Druckschriften seiner Zeit: ein Beitrag zur Geschichte des westlichen Russlandbildes, Bern and Frankfurt a/M. 1972.

Kempa T., Strubicz Maciej, w: Polski słownik biograficzny, t. 44, Kraków 2006-2007.

Kermode F., Poetry and History, w: idem, Poetry, Narrative, History, Cambridge, MA, 1990.

Kochanowski J., Jezda do Moskwy, w: idem, Dzieła polskie, oprac. J. Krzyżanowski, Warszawa 1980.

Kochanowski J., Lyricorum libellus, edycja internetowa na portalu neolatina.bj.uj. edu.pl, transkr. i przekł. E. Buszewicz, objaśn. E. Buszewicz, J. Niedźwiedź (2009).

Kochanowski J., Pieśni, oprac. L. Szczerbicka-Ślęk, Wrocław 2008.

Kochanowski J., Pieśni trzy. O wzięciu Połocka. O statecznym studze R.P. O uczciwej matżonce, Warszawa 1583.

Korolko M., Seminarium Rzeczypospolitej Królestwa Polskiego. Humaniści w kancelarii królewskiej Zygmunta Augusta, Warszawa 1991.

Koźmian K., Wybór poezji. Ody napoleońskie. Wiersze różne. Ziemiaństwo polskie (fragmenty). Stefan Czarniecki (fragmenty), wyd. R. Dąbrowski, Kraków 2002.

Krzycki A., Cantilena de victoria a Moscis parta die natali Sanctae Mariae 1514 rem summarie continens, w: A. Krzycki, Carmina, wyd., wstęp i oprac. K. Morawski, Kraków 1888. 
Krzywy R., „Chcesz być groźnym, a uciekasz...”: nad komentarzem do epinikionów moskiewskich Jana Kochanowskiego, „Pamiętnik Literacki” 104 (2013), z. 3.

Krzywy R., Sztuka wyborów i dar inwencji. Studium o strukturze gatunkowej poematów Jana Kochanowskiego, Warszawa 2008.

Łopatecki K., Oblężenie i zdobycie warownej twierdzy połockiej przez Najjaśniejszego Króla Polski Stefana - analiza założeń taktycznych w świetle źródeł kartograficznych, „Terminus” 19 (2017), 3 (44) (w oprac. red.).

Marotti A.F., Patronage, Poetry, and Print, „The Yearbook of English Studies” 21 (1991): Politics, Patronage and Literature in England 1558-1658. Special Number.

Martinelli А. [А. Мартинелли], История взятия Полоцка польским королем Стеффаном Баторием в 1579 году. Предисловие, подготовка текста и перевод И. В. Дубровский, „Русский сборник. Исследования по истории России" 21 (2017), s. 7-100.

Mączak J., Nierówna przyjaźń. Układy klientalne w perspektywie historycznej, Wrocław 2003.

Mercator G., Atlas sive Cosmographicae meditationes de fabrica mundi et fabricati figura, Amsterdam: Jodocus Hondius, 1613.

Mund S., Orbis Russiarum. Genèse et dévelopment de la représentation du monde „russe” en Occident à la Renaissance, Genève 2003.

Musin A., „Ród ruski”, „ród wareski” i narodowość staroruska „Orientalia Christiana Cracoviensia" 4 (2012).

Niedźwiedź J., Atlas Księstwa Połockiego Stanisława Pachołowieckiego (1580): propaganda, genologia i tworzenie wiedzy geograficznej, „Terminus” 19 (2017), z. 1 (42).

Niedźwiedź J., Humanistyczna mapa Europy Jana Kochanowskiego (Pieśn 24 Ksiąg wtórych), w: Literatura renesansowa w Polsce i Europie. Studia dedykowane Profesorowi Andrzejowi Borowskiemu, red. J. Niedźwiedź, Kraków 2016.

Norbrook D., Poetry and Politics in the English Renaissance, London 1984.

Nowak-Dłużewski J., Okolicznościowa poezja polityczna w dawnej Polsce. Czasy zygmuntowskie, Warszawa 1966.

Nowak-Dłużewski J., Okolicznościowa poezja polityczna w Polsce. Pierwsi królowie elekcyjni, Warszawa 1969.

Pachołowiecki S., Obsidio et expugnatio munitissimis arcis Polocensis, Roma: G.B. Cavalieri, 1580.

Pelc J., Jan Kochanowski. Szczyt renesansu w literaturze polskiej, Warszawa 1980.

Piotrowski J., Dziennik wyprawy Stefana Batorego pod Psków, wyd. A. Czuczyński, Kraków 1894.

Piwarski K., Niedoszła wyprawa radoszkowicka Zygmunta Augusta na Moskwę (rok 1567-1568), „Ateneum Wileńskie” 4 (1927).

Pollak M., Cities at War in Early Modern Europe, New York 2010.

Pszczołowska L., Wiersz polski. Zarys historyczny, Wrocław 1997. 
Quint D., Epic and Empire. Politics and Generic Form from Virgil to Milton, Princeton 1992.

Ryczek W., Słodkobrzmiace pieśni. Epinicion Jana Kochanowskiego - (re)konstruowanie poetyki, w: Wiązanie sobótkowe. Studia o Janie Kochanowskim, red. E. Lasocińska, W. Pawlak, Warszawa 2015.

Tygielski W., Listy, ludzie, władza. Patronat Jana Zamoyskiego w świetle korespondencji, Warszawa 2007.

Kowalczyk J., Jan Kochanowski i Jan Zamoyski, w: Jan Kochanowski i epoka Renesansu. W 450 rocznice urodzin poety 1530-1980, red. T. Michałowska, Warszawa 1984.

Woodward D., Cartography and the Renaissance: Continuity and Change, w: The History of Cartography, t. 3, Cartography in the European Renaissance, red. D. Woodward, Chicago 2007.

Weintraub W., Jan Kochanowski i Joannes Cochanovius: dwóch świadków historii, w: Dzieło literackie jako źródło historyczne, red. Z. Stefanowska, J. Sławiński, Warszawa 1978.

\section{ILUSTRACJE}

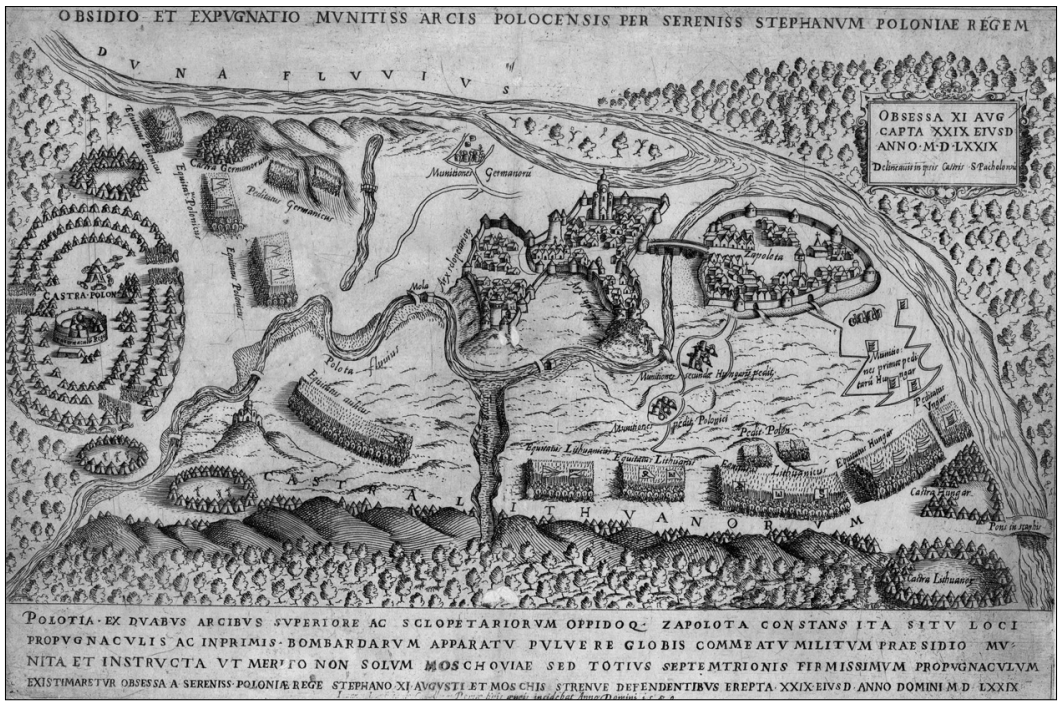

Il. 1. Oblężenie Połocka w 1579 roku. S. Pachołowiecki, Obsidio et expugnatio munitissimae arcis Polocensis, Roma: G.B. Cavalieri, 1580, stan II (Biblioteca Augusta, Perugia, sygn. 2c St serie I 63). Dzięki uprzejmej zgodzie Biblioteca Augusta w Perugii 


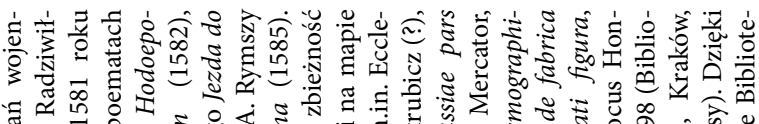

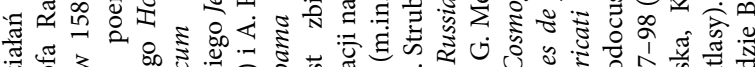

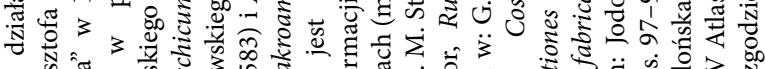

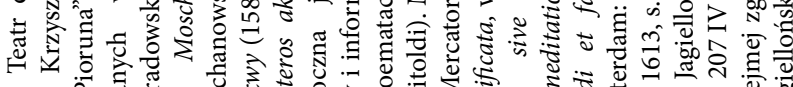
ن

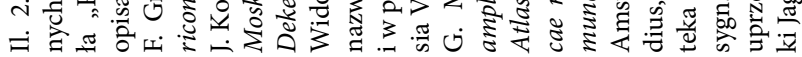

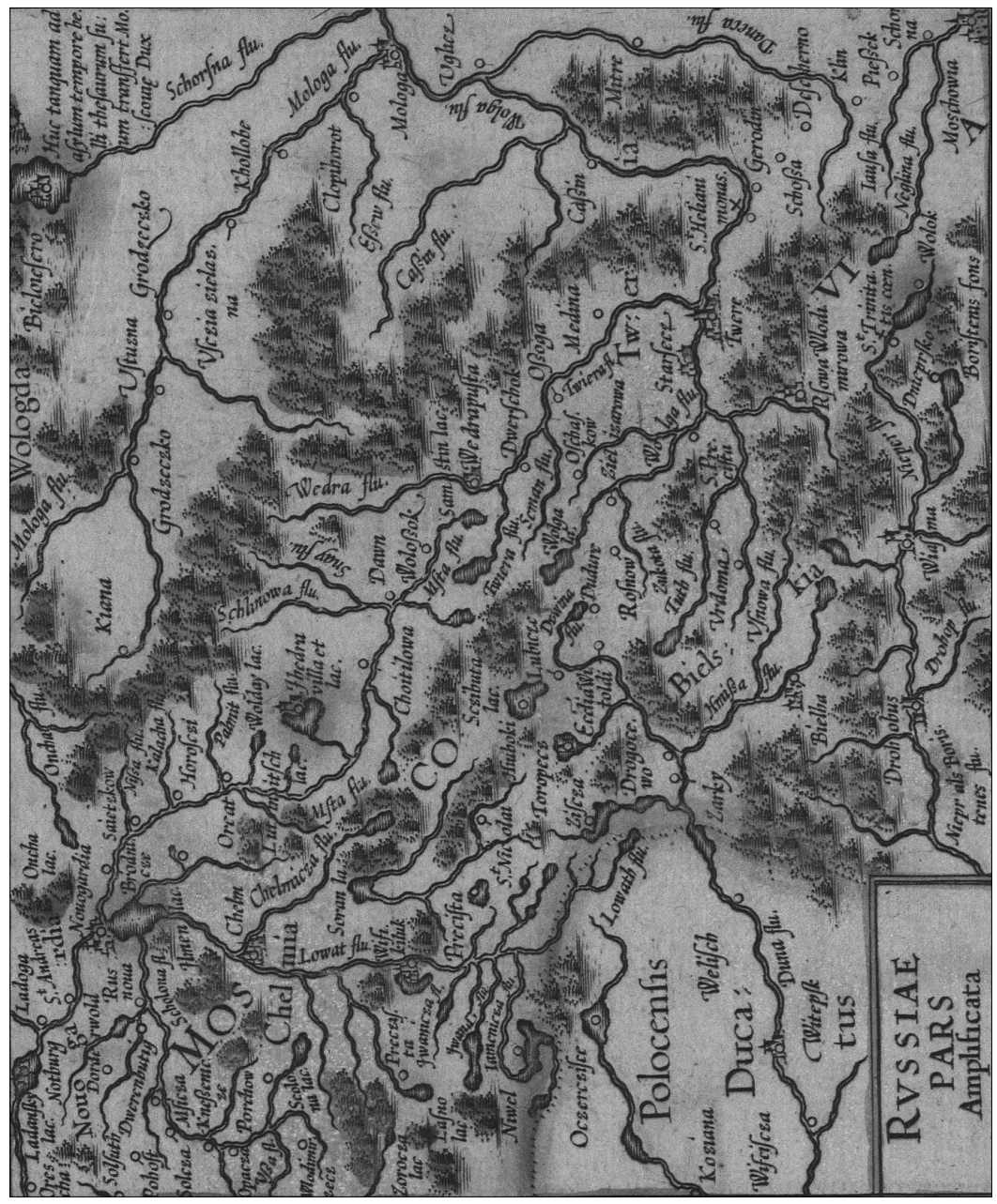

